\title{
Chitosan for direct bioflocculation of wastewater
}

\author{
Eric Lichtfouse ${ }^{1}\left[\right.$ ] Nadia Morin-Crini ${ }^{2}$ (1) Marc Fourmentin $^{3} \cdot$ Hassiba Zemmouri $^{4}$. \\ Inara Oliveira do Carmo Nascimento ${ }^{5}$. Luciano Matos Queiroz ${ }^{5}$ Mohd Yuhyi Mohd Tadza $^{6}$.

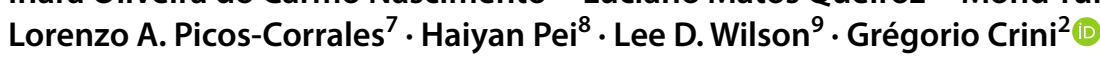

\begin{abstract}
Coagulation/flocculation is a major phenomenon occurring during industrial and municipal water treatment to remove suspended particles. Common coagulants are metal salts, whereas flocculants are synthetic organic polymers. Those materials are appreciated for their high performance, low cost, ease of use, availability and efficiency. Nonetheless, their use has induced environmental health issues such as water pollution by metals and production of large amounts of sludges. As a consequence, alternative coagulants and flocculants, named biocoagulants and bioflocculants due to their biological origin and biodegradability, have been recently developed for water and wastewater treatment. In particular, chitosan and chitosan-based products have found applications as bioflocculants for the removal of particulate and dissolved pollutants by direct bioflocculation. Direct flocculation is done with water-soluble, ionic organic polymers without classical metalbased coagulants, thus limiting water pollution. Chitosan is a partially deacetylated polysaccharide obtained from chitin, a biopolymer extracted from shellfish sources. This polysaccharide exhibits a variety of physicochemical and functional properties resulting in numerous practical applications. Key findings show that chitosan removed more than $90 \%$ of solids and more than $95 \%$ of residual oil from palm oil mill effluents. Chitosan reduced efficiently the turbidity of agricultural wastewater and of seawater, below 0.4 NTU for the latter. $99 \%$ turbidity removal and $97 \%$ phosphate removal were observed over a wide $\mathrm{pH}$ range using 3-chloro-2-hydroxypropyl trimethylammonium chloride grafted onto carboxymethyl chitosan. Chitosan also removed $99 \%$ Microcystis aeruginosa cells and more than 50\% of microcystins. Here, we review advantages and drawbacks of chitosan as bioflocculant. Then, we present examples in water and wastewater treatment, sludge dewatering and post-treatment of sanitary landfill leachate.
\end{abstract}

Keywords Chitosan $\cdot$ Bioflocculant $\cdot$ Direct bioflocculation $\cdot$ Wastewater treatment $\cdot$ Sludge dewatering

\section{Introduction}

Coagulation and flocculation are two frequently applied processes in the water treatment industry for solids removal, water clarification, drinking water treatment, decontamination of wastewaters, removal of target substances, i.e., phosphates, oils, color and odor, solids dewatering, sludge thickening and lime softening (Bratby 2006; Oladoja 2015; Morin-Crini and Crini 2017; Wei et al. 2018). Other applications include the recovery of valuable products such as

Eric Lichtfouse

eric.lichtfouse@gmail.com

Grégorio Crini

gregorio.crini@univ-fcomte.fr

Extended author information available on the last page of the article proteins and microalgae. Coagulation and flocculation involve chemical reagents to facilitate the removal of suspended and colloidal particles, this is often the first stage of solid-liquid separation in a wastewater treatment plant, named the pre-treatment step. Nonetheless, the coagulation-flocculation process can also be applied as a main treatment or even as a post-treatment. During wastewater treatment, coagulation and flocculation occur in two main successive steps (Fig. 1), namely a destabilization step and an aggregation step, respectively (Bratby 1980; Cox et al. 2007). These processes combine insoluble particles, e.g. solids and colloids, dissolved organic matter, organics, inorganics and microorganisms into large aggregates, thereby facilitating their removal in subsequent sedimentation and filtration stages (Bratby 2006; Vajihinejad et al. 2019). Coagulation/flocculation is also a major phenomenon in 


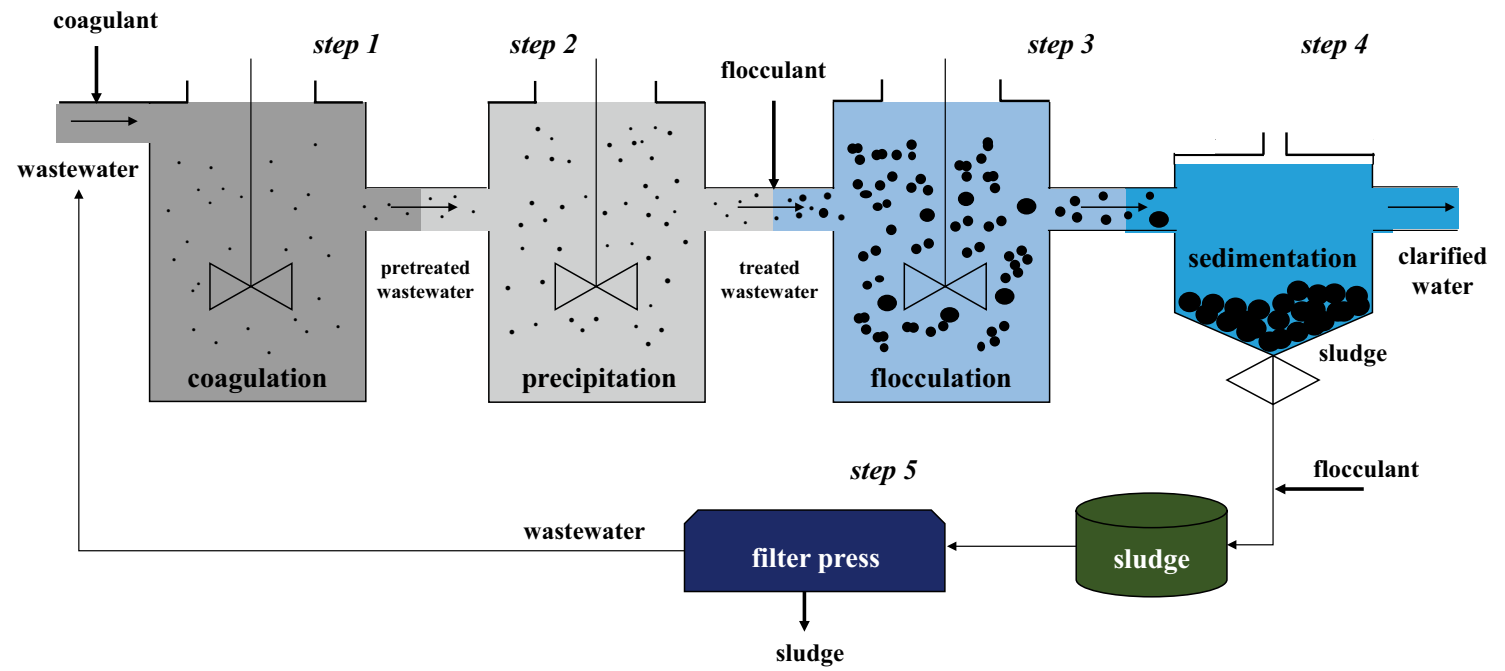

Fig. 1 The coagulation/flocculation process in a physicochemical wastewater treatment plant. In the first step, an inorganic coagulant such as a metal salt is first added (step 1) to alter the physical state of dissolved and suspended solids, in order to induce complex precipitates of metal hydroxides at the desired $\mathrm{pH}$ (step 2: precipitation), and to facilitate sedimentation (step 4). This is followed by the addi-

sludge dewatering. Actually, sludges are a major challenge for the water treatment industry, in particular the minimization of sludge volume. Sludge dewatering separates sludge into liquid and solid components, aiming at waste minimization and cost efficiency for disposal or recycling.

There are actually two major classes of commercial chemicals for coagulation and flocculation: (1) inorganic and organic coagulants such as mineral additives, hydrolyzing metal salts, pre-hydrolyzed metals and polyelectrolytes; and (2) organic flocculants including cationic and anionic polyelectrolytes, nonionic polymers, amphoteric and hydrophobically modified polymers, and naturally occurring flocculants (Bratby 2006; Bolto and Gregory 2007). Coagulation is mainly induced by metal salts. Common metal coagulants fall into two categories: aluminum and iron. The most common coagulants are aluminum sulfate, generally known as alum, polyaluminum chloride (PAC), ferric chloride, ferric sulfate and polyferric sulfate (PFS). Their cations contribute to colloidal destabilization because they specifically interact with and neutralize negatively charged colloids (Stechemesser and Dobiáš 2005; Bratby 2006). Their success arises not only from their effectiveness but also from their availability and low cost. Flocculants are classified into polymeric inorganic-based materials and polymeric organicbased materials. Noteworthy, polyelectrolyte flocculants are in general linear or branched organic macromolecules. These materials can be synthetic or of natural origin. Synthetic macromolecules are produced using various monomers such tion of coagulant aids or flocculants (step 3) to enhance the treatment efficiency and sedimentation rate by mechanical aggregation of micro-flocs into visible, dense and rapid settling flocs. The filter press (last step 5) is an equipment allowing to filtrate sludge under pressure in order to separate the liquid (filtrate) and the solid phase (the cake)

as acrylamide, acrylic acid or dimethyldiallylammonium chloride. Naturally occurring polymers include starches, celluloses, alginates, gums and other plant derivatives (Levine 1981). The main flocculants used in industrial applications are polyacrylamide-based products such as nonionic polyacrylamides, anionic acrylamide-acrylate copolymers, partially hydrolyzed polyacrylamides, cationic dimethyldiallylammonium chlorides and copolymers of the dimethyldiallylammonium ion with acrylamide. Their main advantage is their ability to produce large, dense, compact flocs that are stronger and have good settling characteristics compared to those obtained by coagulation. Polymeric organic flocculants are also easy to handle and immediately soluble in aqueous systems. They reduce the sludge volume.

Nonetheless, the use of synthetic coagulants and flocculants poses environmental and health issues. For instance, the major issues are production of large volumes of toxic sludge, low biodegradability, pollution of water by metals, which may threaten human health, e.g. aluminum salts are connected to Alzheimer's disease, and dispersion of acrylamide oligomers, which is a health hazard because the acrylamide monomer is carcinogenic and neurotoxic to humans (Salehizadeh et al. 2018). For these reasons, alternative natural materials, named biocoagulants and bioflocculants, have been developed for wastewater treatment (Crini et al. 2019). In particular, chitosan, a partially deacetylated polysaccharide obtained from chitin, deserves particular attention. Chitosan is an amino-polysaccharide, 
it is non-toxic, biocompatible, biodegradable and classified as a green product (Morin-Crini et al. 2019). The cationic biopolymer chitosan has also drawn particular attention as a flocculating agent for application in water industries due to its eco-friendly character, low cost and outstanding performances.

From the end of the 2000s, Crini's group proposed direct bioflocculation using low-cost chitosan as a novel approach to treat wastewater from pulp and paper plant (Crini et al. 2009a, b; Renault et al. 2009a, b, c, d). Their results indeed demonstrated that chitosan combines both functions of coagulation and flocculation during industrial wastewater treatment. Crini thus spoke of two-in-one materials (Crini and Badot 2007; Crini et al. 2009a, b). Several recent reviews have demonstrated that direct bioflocculation is an effective and competitive approach, and that chitosan is a promising bioflocculant for environmental and purification purposes (Chong 2012; Lee et al. 2014; Crini 2015; Bhalkaran and Wilson 2016; Laamanen et al. 2016; Yang et al. 2016; Kanmani et al. 2017; Ummalyma et al. 2017; Wang and Zhuang 2017; Desbrières and Guibal 2018; Pakdel and Peighambardoust 2018; Song et al. 2018; Salehizadeh et al. 2018, Van Tran et al. 2018; Crini et al. 2019; Vidal and Moares 2019).

In this review, after a brief description of the main advantages and possible disadvantages of using chitosan as a bioflocculant, we highlight key results on chitosan applications such as water and wastewater treatment, sludge dewatering and post-treatment of sanitary landfill leachate. This article is an abridged version of the chapter published by Lichtfouse et al. (2019) in the series Sustainable Agriculture Reviews.

\section{Application of chitosan as bioflocculant}

\section{Coagulation-flocculation versus direct flocculation}

Polymeric flocculants, especially cationic polymers, can be used for direct flocculation because they possess dual functions of coagulation and flocculation, i.e., neutralizing the negative charges and bridging aggregated destabilized particles. Indeed, direct flocculation, i.e., without addition of coagulants, but using ionic polymers, offers the possibility to completely replace inorganic coagulants by water-soluble organic polymers in chemical pre-treatment, main treatment, or post-treatment. The selection between conventional coagulation-flocculation and direct flocculation is highly dependent on the type of wastewater. In general, the applications of direct flocculation using solely polymeric flocculants are mostly limited to organic-based wastewater containing high concentration of suspended and colloidal solids, such as food, paper and pulp and textile effluents (Morin-Crini et al. 2019). Soros et al. (2019) recently proposed chitosan for turbidity reduction in drinking water to reduce microbes and organic matter. The authors concluded that chitosan is promising for turbidity reduction in low-resource settings, if chitosan treatment is combined with sedimentation and filtration.

\section{Direct bioflocculation using chitosan}

During the last two decades there has been a fast rise in the use of chitosan as bioflocculant, and in the development of new chitosan-based materials, e.g., grafted chitosans, composites and hybrid materials, for direct bioflocculation processes. The main potential applications are in water and wastewater treatment, sludge dewatering and harvesting of microalgae, and dissolved air flotation (Chong 2012; Lee et al. 2014; Yang et al. 2016; Morin-Crini et al. 2019; Vidal and Moares 2019). Table 1 describes the main characteristics and properties of chitosan applied to flocculation. Table 2 presents the main disadvantages of chitosan as bioflocculant.

\section{Mechanism}

Similar to classical flocculation, bioflocculation by chitosan involves combining insoluble particles and dissolved organic matter into larger aggregates, which can be then removed in subsequent sedimentation and filtration stages (Morin-Crini et al. 2019; Vidal and Moares 2019). Chitosan chains first destabilize suspended and colloidal particles in wastewater by forming micro-flocs in the coagulation step. Micro-flocs are then aggregated in the flocculation step, which requires an agitation that induces particles to clump, thus allowing solid removal in subsequent stages. The mechanism (Fig. 2) is mainly driven by charge neutralization and bridging mechanisms. Other mechanisms such as electrostatic patch and sweeping, adsorption, entrapment, complexation, chelation and precipitation may also contribute to bioflocculation. Charge neutralization refers to the interaction of two particles with opposite charged ions, whereas sweep flocculation entails the enmeshment of particles in a growing precipitate. Polymer chains agglomerate particles by inter-particle bridging. This phenomenon involves the adsorption of particles onto polymer chains by forming particle-polymer-particle complexes. The loops and tails of adsorbed polymer chains protrude and attach to other particles in the aqueous solution, allowing bridging of particles. This explains that chitosan has the ability to enhance dissolved pollutant removal such as metal ions. Electrostatic 
Table 1 Properties of chitosan for flocculation-based applications

Main characteristics and properties

Raw chitosan for water treatment applications: low-cost product. Chitin: is a renewable resource obtained from industrial by-products

Non-toxic, biocompatible and biodegradable

Eco-friendly biopolymer; ecologically acceptable product

Linear amino-polysaccharide with high nitrogen content; weak base and powerful nucleophile

Hydrophilic biopolymer with high reactivity

Reactive amino and hydroxyl groups for modification

Polyelectrolyte at acidic $\mathrm{pH}$ with high charge density: a polycationic biopolymer

Ionic conductivity

Gelation ability, adhesivity, film-forming ability

Ability to form hydrogen bonds and other non-covalent interactions

Ability to encapsulate, entrapment properties

Chelation, ion-exchange and adsorption properties

Removal of pollutants or pollutions, e.g. color, and odor, with outstanding performances

Strong adsorption to negatively-charged surface of microalgae cells

Formation of salts with organic and inorganic acids

Efficient against bacteria, viruses and fungi

Chitosan is less sensitive to $\mathrm{pH}$ changes than metal salts

Chitosan coagulates microalgae cells very effectively and produces larger flocs than polyaluminium chloride

References Skjåk-Braek et al. (1989), Roberts (1992), No and Meyers (1995), Peters (1995), Goosen (1997), Kurita (1998, 2006), Ravi Kumar (2000), Domard and Domard (2001), Dutta et al. (2004), Vårum and Smidsrød (2004), Rinaudo (2006), Li et al. (2008), Crini et al. (2009a, b), de Alvarenga (2011), Sudha (2011), Nwe et al. (2011), Teng (2016), Nechita (2017), Morin-Crini et al. (2019), Vidal and Moraes (2019)

Table 2 Drawbacks of chitosan-based bioflocculants for water and wastewater treatments applications

Technologies are still being developed: to be confirmed at scale up levels

Cost limitation: chitosan is considered cost prohibitive to purchase for use as a microalgae bioflocculant

Chitosan is not water soluble, it requires a weak acid treatment to be dissolved. Chitosan solubility depends on the degree of deacetylation and molecular weight

Variability in the chitosan characteristics and in the materials used; performances depend on type of raw chitosan, chitosan activation and chitosan-based materials

Chitosan is a very efficient flocculant but only at low $\mathrm{pH}$ : $\mathrm{pH}$-dependent behavior

The amount used is in general high; chitosan concentration should be monitored to avoid re-stabilization. Re-stabilization is induced by an excess of cationic charges at high chitosan concentration

Possible clogging of filters at high concentration

Chitosan requires chemical modification to improve its performance, to decrease its $\mathrm{pH}$ sensitivity and to enlarge the field of its potential applications; the efficiency depend on the functional groups grafted

Bioflocculation using chitosan is not universal to all pollutant types, e.g., it was found effective for green microalgae but gave poor results for cyanobacteria

References No and Meyers (2000), Crini et al. (2009a, b), Renault et al. (2009a), Ujang et al. (2011), Lee et al. (2014), Yang et al. (2016), Sudha et al. (2017), Morin-Crini et al. (2019), Vidal and Moares (2019)

patching is caused by the interaction of polymer chains of high charge density with oppositely-charged colloidal particles of low charge density. A polymer-colloidal particle patch can then attach another colloidal particle if their charges are opposite. Overall, chitosan forms a bulky precipitate that enmeshes colloidal particles, this is the sweeping mechanism. These particles are then settled out or they flocculate together with the precipitate (Stechemesser and Dobiáš 2005; Abebe et al. 2016).

\section{Chitosan for direct bioflocculation: potential applications}

\section{Palm oil mill effluents}

The main challenge of palm oil-producing countries is the production of palm oil mill effluents in large amounts. In Malaysia alone, approximately 50 to 75 million tons of 
Fig. 2 The bioflocculation mechanism: a charge neutralization, $\mathbf{b}$ bridging, $\mathbf{c}$ electrostatic patching and $\mathbf{d}$ sweeping (a)

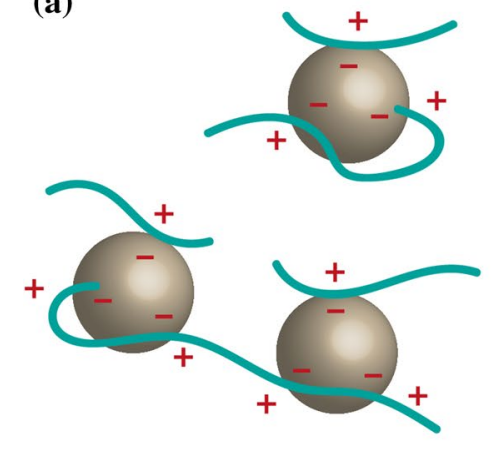

(c)

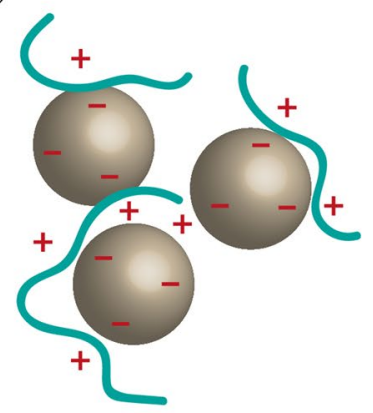

(b)

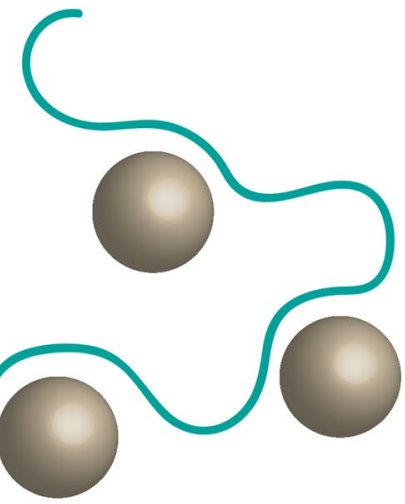

(d)

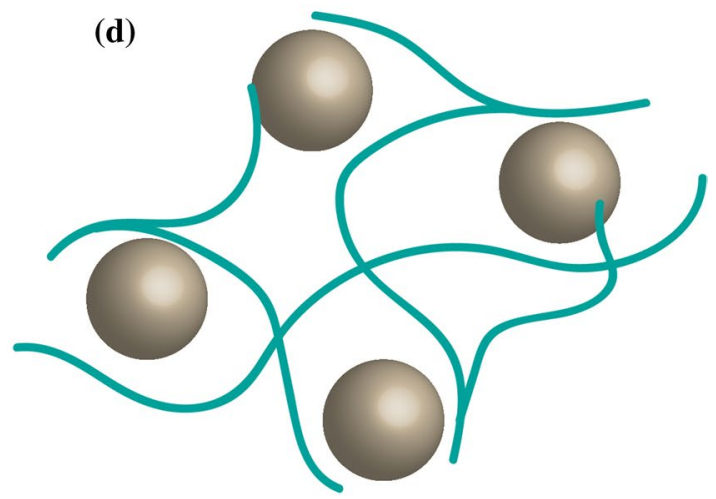

palm oil mill effluents are produced annually (Ding et al. 2016). The effluent is a thick brownish colloidal mixture of various elements including water, oil and suspended particles (Bala et al. 2015). Freshly generated palm oil mill effluent is usually discharged between 80 and $90{ }^{\circ} \mathrm{C}$ and is acidic in nature, having an average $\mathrm{pH}$ value of about 4.5. This dark liquid typically contains substantial amounts of suspended solids, oil and grease, and shows high concentrations of biochemical and chemical oxygen demand (BOD, COD). Table 3 presents typical characteristics of raw and treated palm oil mill effluents.

Illegal discharge of raw or partially treated palm oil mill effluents into nearby water bodies or land is common and still being practiced, as this is the easiest and cheapest option for disposal (Tadza et al. 2015). However, due to stricter regulatory discharge limits and increasing environmental awareness, palm oil mill effluents are now treated prior to being discharged into the environment. Currently, integrated biological and physicochemical methods are commonly used for the treatment of raw effluents. Since the effluent is largely biodegradable, biological treatments appeared to be the most viable treatment methods. Therefore, open aerobic or anaerobic ponding systems have been used widely. Yet, ironically, the final discharged effluents from conventional ponding systems have often failed to conform to regulatory discharge limits (Rushdy et al. 2014; Bello and Raman 2017). Furthermore, the lignin-tannin compounds, which are responsible
Table 3 Characteristics of raw and treated palm oil mill effluents and discharge limits. COD: chemical oxygen demand; BOD: biochemical oxygen demand; TSS: total suspended solids

\begin{tabular}{lllll}
\hline Parameters & Unit & Raw effluent & Treated effluent & $\begin{array}{l}\text { Discharge } \\
\text { limits }\end{array}$ \\
\hline $\mathrm{pH}$ & & 4.2 & 8.4 & $5.0-9.0$ \\
Temperature & ${ }^{\circ} \mathrm{C}$ & $85-90$ & $25-30$ & 45 \\
$\mathrm{COD}$ & $\mathrm{mg} / \mathrm{L}$ & 50,000 & 4500 & - \\
$\mathrm{BOD}$ & $\mathrm{mg} / \mathrm{L}$ & 35,000 & 450 & 100 \\
oil, grease & $\mathrm{mg} / \mathrm{L}$ & 6000 & - & 50 \\
$\mathrm{TS}$ & $\mathrm{mg} / \mathrm{L}$ & 40,000 & - & 1500 \\
$\mathrm{TSS}$ & $\mathrm{mg} / \mathrm{L}$ & 18,000 & 130 & 400 \\
$\mathrm{NH}_{4}-\mathrm{N}$ & $\mathrm{mg} / \mathrm{L}$ & 180 & 20 & 100 \\
$\mathrm{PO}_{4}{ }^{3-}$ & $\mathrm{mg} / \mathrm{L}$ & 210 & - & - \\
Turbidity & $\mathrm{NTU}$ & 430 & 100 & - \\
Color & $(\mathrm{PtCo})$ & 32,000 & 250 & - \\
\hline
\end{tabular}

References Wu et al. (2010), Chan et al. (2011), MPOB (2012), Bello et al. (2013), Bala et al. (2015), Tadza et al. (2015, 2016), Saeed et al. (2016)

for the dark coloration of palm oil mill effluents, are recalcitrant to biological treatment and should be further treated using secondary treatments or polishing methods.

To date, the use of chitosan for the treatment of palm oil mill effluents is very limited. Chitosan and its derivatives have been found effective coagulation agents for treating 
both raw and treated palm oil mill effluents. For instance, Ahmad et al. (2005a, b) noted that powdered and flake chitosan is effective for the removal of solids $(>90 \%)$ and residual oil ( $>95 \%$ ) from palm oil mill effluents. The results showed that chitosan performed better compared to other natural absorbents such as bentonite, zeolite and activated carbon. The performance of chitosan was better than that of alum and polyaluminum chloride. The removal of residual oil and reduction in the total solid concentrations in palm oil mill effluents is $\mathrm{pH}$ dependent. The removal efficiency is lower with increasing $\mathrm{pH}$. Yet, the strong acidic properties of palm oil mill effluents enhance the coagulation of the residue oil in the effluent. Under acidic conditions, chitosan induces a physicochemical effect, serves as demulsifying agent and enhances the adsorption of oil and grease (Ahmad et al. 2005a). This is explained by the availability of protons, which increases the number of protonated amine groups of chitosan molecules. On the other hand, adsorptive removal of heavy metals using chitosan alone has not been very successful.

Apart from raw powdered and flake chitosan, the derivatives of chitosan have also been used to treat palm oil mill effluents. This involves dissolving powdered chitosan with acid solutions (Ahmad et al. 2006; Torres et al. 2018). In some cases, chitosan is mixed with other oxidative chemicals such as ferric chloride, ferrous sulfate and hydrogen peroxide (Parthasarathy et al. 2016; Tadza et al. 2016). These investigations showed improved solids removal and significant increases in the removal efficiency of the chemical oxygen demand compared to using powdered chitosan alone. For instance, chitosan coagulation coupled with hydrogen peroxide is a better alternative for the post-treatment of anaerobically digested palm oil mill effluents due to its improved treatment efficiency, environmental safety and availability. Although no explanation was made on the possible reasons for this observation, it is presumed that the neutral $\mathrm{pH}$ or the possible interaction between iron and chitosan lead to the reduction of active sites of the iron (Bello and Raman 2017).

Although chitosan has shown remarkable performances in treating palm oil mill effluents, palm oil mills have been still complaisant with ponding systems due to their simplicity and cost-effectiveness. Consequently, almost all reported chitosan studies were conducted under smallscale laboratory conditions. Feasibility studies are yet to be scaled up. Despite the potentials of chitosan, a lot of effort is thus required in upscaling to the industrial level. Another challenge is to recycle the sludge generated as a by-product of the coagulation process using chitosan. Here, Tadza et al. (2016) showed that the sludge displayed good fertility characteristics and may be considered as fertilizer or soil conditioners.

\section{Effluents from the sugar industry}

Pambi and Musonge (2015) studied the efficiency of chitosan as a coagulant for the treatment of the effluents from the sugar industry to remove both suspended solids, color and chemical oxygen demand. The sugar refinery consumes large amounts of water daily and approximately $47 \%$ of this water is discharged as wastewater. The treatment of effluents by chitosan was investigated under varying chitosan dosage with a study of the effect of $\mathrm{pH}$ on impurity removal performance. Results show that an increase in the chitosan concentration increased the impurity removal efficiency. However, beyond an optimum coagulant concentration, no further improvement was observed. The optimum chitosan loading was $138 \mathrm{mg} / \mathrm{L}$. The impurity content in the effluent was also found to influence the amount of chitosan loading required. High removal efficiencies were achieved under acidic conditions, due the cationic nature of chitosan. However, the removal of the chemical oxygen demand was very low due to the fact that most of the matter present in the effluent was made of dissolved organics. The performance of chitosan was found to be $\mathrm{pH}$ dependent. For instance, the addition of sodium hydroxide raise the $\mathrm{pH}$ strongly decreased the performance of chitosan, due to its possible gelation under alkaline conditions. Furthermor, overdosing the coagulant destabilized the neutralized flocs and, in tun, impeded their settling. Here, the mechanism is explained as follows: first, the cationic charge of the protonated macromolecule destabilized and neutralized the anionic charges of the impurities; second, there was a bridging of the macromolecules with the particles, leading to flocs formation; and finally, electrostatic patching occurs, as described above. Chitosan has thus a dual role, both as a coagulant and flocculant, as a consequence of its charge density and relatively high molecular weight. The authors concluded that chitosan as low-cost biodegradable material is an ideal candidate to substitute conventional synthetic materials.

\section{Agricultural wastewater}

Chitosan can be an alternative for the treatment of effluents containing residual fertilizers and persistent pesticides that contaminate drinking water. As an example, organochlorines pesticides are highly hazardous and have chemical structures that are very difficult to degrade. In agriculture, there is a demand for efficient methods to be developed and applied at an industrial scale, as recently pointed out by Rani et al. (2017).

Rahmanifar and Moradi-Dehaghi (2014) tested the interaction of chitosan and permethrin, an organochlorine pesticide. Batch trials were performed at $\mathrm{pH} \mathrm{7,} \mathrm{shaking} \mathrm{at}$ $150 \mathrm{rpm}$ for $45 \mathrm{~min}$, with chitosan amounts ranging from 0.01 to $1.5 \mathrm{~g}$, added to $25 \mathrm{~mL}$ of a $0.1 \mathrm{ppm}$ permethrin 
solution. The adsorption efficiency increased with adsorbent concentration up to $0.5 \mathrm{~g}$. Thereafter, increasing adsorbent concentrations did not improve substantially the removal, and nearly $50 \%$ removal was reached for dosages between 0.5 and $1.5 \mathrm{~g}$. Yet, the entrapment of a model pesticide was markedly improved, near to $98 \%$, using a nanocomposite form of chitosan- $\mathrm{AgO}$ as adsorbent. In another contribution, the removal of pentachlorophenol, a common pesticide, from aqueous solutions, was assessed by comparing chitosan versus the modified chitosan: [chitosan-(2-hydroxy-1-naphthaldehyde)] (Shankar et al. 2018). The effect of contact time on pesticide adsorption was studied, based on experiments in batch mode, under stirring, where $0.2 \mathrm{~g}$ of adsorbent was added to $200 \mathrm{~mL}$ of a synthetic solution containing the pesticide at $150 \mathrm{mg} / \mathrm{L}$. Results showed fast initial removal, which was explained by the availability of vacant sites for adsorbent-pesticide interactions. After $60 \mathrm{~min}$, the maximum adsorption capacity was almost reached for both biosorbents. The adsorption capacity exhibited by chitosan, of $24.4 \mathrm{mg} / \mathrm{g}$ at neutral $\mathrm{pH}$, was enhanced by $94 \%$ using the modified chitosan. The adsorption capacity decreased by rising the $\mathrm{pH}$ from 3.0 to 8.0 , explained by higher contaminant solubility and $p K_{\mathrm{a}}$ of 4.7 , as well as for higher temperatures in the range of $+20-40{ }^{\circ} \mathrm{C}$ for the unmodified and modified forms of chitosan.

Model wastewaters containing the commercial pyrethroid and dithiocarbamate pesticides were treated for pesticide removal by employing chitosan (Ghimici et al. 2016). Results show a similar maximum removal efficiency, nearly $90 \%$, for both pesticides. Chitosan showed good flocculation at low doses from 1 to $3.4 \mathrm{mg} / \mathrm{L}$ for $\alpha$-cypermethrin, deltamethrin and mancozeb as active ingredients. Here, the analysis of zeta potential measurements suggested that the flocculation of particles took place mainly via charge neutralization. Noteworthy, the efficiency of the treatment may be very different using real agricultural effluents instead of synthetic samples. Indeed, real effluents contain many interferring organic and inorganic compounds. Nevertheless, Ruelas-Leyva et al. (2017) showed the high efficiency of chitosan for turbidity removal using samples of raw agricultural wastewater with $36 \mathrm{NTU}$ and $\mathrm{pH}$ conditions close to 7.5. Their experiments involved direct bioflocculation starting with stirring at $100 \mathrm{rpm}$ for $5 \mathrm{~min}$, afterward $60 \mathrm{rpm}$ for $30 \mathrm{~min}$ and then $30 \mathrm{~min}$ of undisturbed settling; the $\mathrm{pH}$ of samples was not manipulated. Results show that an increase in the chitosan concentration reduced the turbidity, and for concentrations higher than $10 \mathrm{mg} / \mathrm{L}$, the turbidity was constant, below 5 NTU. In this study, the removal mechanism was sweep flocculation. To conclude, more experiments are required using chitosan for the remediation of raw agricultural wastewater, where the efficiency of the simultaneous removal of residual fertilizers and pesticides such as fungicides and herbicides should be addressed.

\section{Pre-treatment of seawater}

One of the problems the desalination industry is the fouling that takes place due to the poor quality of the influent seawater received for treatment, especially when it rains. In such a situation, the seawater reaching the desalination plant displays a high turbidity. Altaher (2012) studied the removal of the turbidity of seawater by chitosan. The results demonstrated that chitosan dissolved in hydrochloric acid was efficient to remove turbidity from seawater in alkaline medium. The final turbidity of the seawater after treatment followed by conventional sand filtration was very low, of $0.433 \mathrm{NTU}$. The following conditions were used: optimum dose of $18 \mathrm{mg} / \mathrm{L}$ — compared to $1200 \mathrm{mg} / \mathrm{L}$ for alum—with $250 \mathrm{rpm}$ of rapid stirring for $5 \mathrm{~min}$ and $30 \mathrm{~min}$ of slow stirring at $50 \mathrm{rpm}$ followed by $30 \mathrm{~min}$ of settling. The turbidity removal efficiency of chitosan dissolved in $\mathrm{HCl}$ and chitosan dissolved in acetic acid, alum and ferric chloride was $97.6 \%$, $86.9 \%, 98 \%$ and $90 \%$, respectively. The turbidity removal efficiency of chitosan dissolved in hydrochloric acid was high compared to that obtained from chitosan dissolved in acetic acid. The performance of chitosan was better than that of ferrous sulfate, though similar to alum. The results were explained by charge neutralization and bridging mechanisms. The author also suggested that chitosan initially dissolved in acid media could precipitate when diluted into alkaline solutions. This precipitation may be responsible for the removal of suspended solids by sweeping. Throughout the experiments, no $\mathrm{pH}$ adjustment was required since chitosan performed well even in the alkaline $\mathrm{pH}$ of sea water. The main effect on performance depends on the molecular weight of the chitosan. Altaher (2012) concluded that chitosan might be a potential replacement for metal coagulants due to its high turbidity removal efficiency even at high $\mathrm{pH}$ of treated water, availability and safe usage.

\section{Amphoteric chitosan for phosphate removal}

The fate and transport of oxoanion species such as orthophosphate $P_{\mathrm{i}}$ in aquatic environments are concerns for human and ecosystem health due to the effects of eutrophication and excessive algae growth, as described in detail elsewhere (Agbovi and Wilson 2017, 2018; Schindler et al. 2012). While the use of synthetic flocculants offers an approach for the controlled removal of anion species in water and wastewater, there are concerns on the toxicity and secondary pollution effects arising from the use of potentially harmful organics such as polyacrylamide and metal species such as aluminum sulfate or alum for coagulation-flocculation processes. Based on the inspiration from the seminal contributions reported by Crini and coworkers, along with Renault et al. (2009a, b), Wilson' group has developed an interest in the potential use of chitosan as an 
alternative biopolymer versus synthetic coagulant-flocculant systems. As outlined above, chitosan has been reported to have dual function as a coagulant or flocculant due to its polycationic character at $\mathrm{pH}$ conditions near or below its $p K_{\mathrm{a}}$ of about 6.3, along with its unique properties as a biopolymer material. Commercially available chitosan typically has a degree of deacetylation of about $75-85 \%$, and a variable $p K_{\mathrm{a}}$ of 5.5-6.5, which depends on its molecular weight and degree of deacetylation (Muzzarelli 1973). Depending on the $\mathrm{pH}$ of the medium, chitosan may possess amphoteric-like properties that are advantageous for applications in flocculation-coagulation processes. This is explained by the protolytic equilibria of chitosan and the key role of inorganic or organic acid additives that favour chitosan dissolution in aqueous media. The unique polycation nature of chitosan has led to its application as a versatile flocculant-coagulant for the destabilization of colloidal dispersions, especially dispessions with negative ionic charges or negative zeta potential (Wilson 2014), since a key step in the overall coagulation-flocculation process involves charge neutralization, as explained above.

From the viewpoint of water treatment processes, anion removal in water and wastewater treatment is a key challenge that differs uniquely from the removal of cation species (Wilson et al. 2013; Steed and Atwood 2009). While the efficacy of soluble chitosan as a complexing agent for anions is well established for flocculation-coagulation processes, the conditions are often restricted to acidic $\mathrm{pH}$ values. The addition of acid species to aid dissolution of chitosan can be overcome via synthetic modification of chitosan amphoteric derivatives by functionalization of the $-\mathrm{OH}$ or $-\mathrm{NHR}(\mathrm{R}=\mathrm{H}$ or acetyl) groups of chitosan, according to its degree of deacetylation. One approach is to functionalize chitosan with anionic groups such as $-\mathrm{R}^{\prime} \mathrm{CO}_{2} \mathrm{H},-\mathrm{R}^{\prime} \mathrm{PO}_{3} \mathrm{H}_{2}$ and $-\mathrm{R}^{\prime} \mathrm{SO}_{3} \mathrm{H}$ where $\mathrm{R}^{\prime}=$ alkyl or aromatic linker of variable size, at the -NHR or -OH sites (Yang et al. 2016). To achieve a permanent cationic character that is $\mathrm{pH}$ independent, chitosan can be functionalized with quaternary ammonium groups such as $-\mathrm{NR}_{3}{ }^{+}$where $\mathrm{R}=\mathrm{alkyl}$, at the $-\mathrm{OH}$ or $-\mathrm{NHR}$ sites ( $c$. Tables 3.3 and 3.5 in Yang et al. 2016). A second strategy is to use mixtures of cationic and/or anionic flocculants along with or without an additive metal salt coagulant. Such types of mixtures confer "amphoteric" properties via blending of components into binary and ternary mixtures, as reported by Agbovi and Wilson $(2017,2018)$. Table 4 lists selected examples of biopolymer flocculants such as alginate, polydiallyldimethyl-ammonium chloride, chitosan and its modified forms, for the removal of orthophosphate $P_{\mathrm{i}}$ species from synthetic and real wastewaters. Additional examples of chitosan-based amphoteric flocculants are described elsewhere (Muzzarelli 1988; Vårum and Smidsrød 2004, Meera and Emilia 2006; Prado and Matulewicz 2014; Quinlan et al. 2015; Besse et al. 2016; Kadokawa 2018).

According to Table 4, the efficacy of biopolymer flocculant-coagulant systems for the removal of orthophosphate $P_{\mathrm{i}}$ is compared with the results reported by Wilson's group (Agbovi et al. 2017; Agbovi and Wilson 2017, 2018) and others. While variable removal efficiency of orthophosphate $P_{\mathrm{i}}$ was achieved, it is noted that the sole use of metal species, e.g., $\mathrm{Al}^{3+}$ or $\mathrm{Fe}^{3+}$, or biopolymer flocculants, such as alginate or chitosan, shows differences according to the relative dosage and $\mathrm{pH}$ conditions. The combined use of metal ion species and its resulting influence on the adsorption properties of chitosan has been described in a recent report by Rashid et al. (2018) in a study of the adsorption properties of chitosan with Reactive Black 5 and other dyes. In the case

Table 4 Examples of phosphate removal from water and wastewater using different types of coagulant-flocculant systems. $S W$ synthetic wastewater, $M W$ municipal wastewater, $R W$ real wastewater, $S E F$ secondary effluent wastewater, $P D D M A C$ polydiallyldimethyl-ammonium chloride

\begin{tabular}{llllll}
\hline Water source & Flocculant system & $\begin{array}{l}\text { Optimum dosage } \\
(\mathrm{mg} / \mathrm{L})\end{array}$ & Optimum pH & Efficiency (\%) & References \\
\hline SW & Alginate & 25 & $5.7-7.0$ & 38 & Agbovi and Wilson (2017) \\
SW & Alum/alginate & $30 / 59$ & $5.7-7.0$ & 80 & Agbovi and Wilson (2017) \\
SW & Fe(III)-alginate & 10 & 4.7 & 99.7 & Agbovi and Wilson (2017) \\
SW & Ferric chloride & 80 & 7.2 & 82 & Yang et al. (2010) \\
RW & Chitosan and alginate & 10,20 & N/A & 80 & Latifian et al. (2014) \\
SW & Chitosan & N/A & $7.5-7.9$ & 60 & Fierro et al. (2008) \\
SW & Chitosan & 0.5 & 4 & 30 & Filipkowska et al. (2014) \\
SW & PDDMAC & 60 & 8 & 59 & Chen and Luan (2010) \\
MW & Chitosan & 10 & 9.5 & 89 & Dunets and Zheng (2015) \\
SEW & Alum & 5 & $4.7-5.9$ & 67.4 & Banu et al. (2007) \\
SW & CMC-Fe(III) & 10 & 4 & 90.6 & Agbovi and Wilson (2018) \\
SW & Chitosan-Fe(III) & 10 & 4 & 93.4 & Agbovi and Wilson (2018) \\
SW & CMC-CTA/Fe(III) & & & Agbovi and Wilson (2018) \\
\hline
\end{tabular}


of polydiallyldimethyl-ammonium chloride, a relatively low flocculant dosage of $0.5 \mathrm{mg} / \mathrm{L}$ was used, where relatively high orthophosphate $P_{\mathrm{i}}$ is noted. The effective removal for polydiallyldimethyl-ammonium chloride is explained by the high binding affinity between polyelectrolytes of opposite ionic charge. The dianion form of orthophosphate $P_{\mathrm{i}}$ exists at this alkaline $\mathrm{pH}$ condition, according to the known $p K_{\mathrm{a}}$ values for orthophosphate, i.e., $p K_{\mathrm{a}, 1}=2.17, p K_{\mathrm{a}, 2}=7.31$ and $p K_{\mathrm{a}, 3}=12.36$ (Wilson and Tewari 2018). In contrast, the flocculation of other systems in Table 7 reported by Agbovi and Wilson was carried out at $\mathrm{pH} 4-5$, where the monoanion $P_{\mathrm{i}}$ species prevails (Agbovi et al. 2017; Agbovi and Wilson 2017, 2018). The combined use of metal salt and biopolymer flocculant reveals enhanced removal of orthophosphate $P_{\mathrm{i}}$, as evidenced by the lower flocculant dosage when used along with metal salts (Table 4). This is consistent with a removal process that follows an electrostatic charge neutralization and an ion-binding adsorption mechanism (cf. Table 2.1; Yang et al. 2016).

The last few entries of Table 4 compare the orthophosphate $P_{\mathrm{i}}$ removal for carboxymethyl-chitosan, chitosan and 3-chloro-2-hydroxypropyl trimethylammonium chloride grafted in the absence of added kaolinite (turbidity). The design and chemical structure of these amphoteric biopolymer flocculants are shown in Scheme 1. The removal efficiency for the biopolymer-Fe(III) systems is listed in descending order: 3-chloro-2-hydroxypropyl trimethylammonium chloride grafted onto carboxymethyl chitosan $>$ chitosan $>$ carboxymethyl chitosan, in accordance with the trends in the relative zeta potential of the biopolymers. In the presence of turbidity, with $400 \mathrm{mg} / \mathrm{L}$ kaolinite and initial orthophosphate $P_{\mathrm{i}}$ at $25 \mathrm{mg} / \mathrm{L}$, 3-chloro-2-hydroxypropyl trimethylammonium chloride grafted onto carboxymethyl chitosan showed greater orthophosphate $\mathrm{P}_{\mathrm{i}}$ removal versus chitosan and carboxymethyl chitosan at all $\mathrm{pH}$ conditions, where optimal turbidity removal of $99.2 \%$ and orthophosphate $P_{\mathrm{i}}$ removal of $97.8 \%$ were observed at $\mathrm{pH} 4$, according to the experimental results shown in Fig. 3.

It can be concluded that enhanced removal of orthophosphate can be achieved through synthetic modification of chitosan, especially in conjunction with Fe(III) coagulants in industrially-relevant wastewater conditions. The performance of amphoteric chitosan flocculants can be tuned for optimal performance at variable $\mathrm{pH}$ conditions in response to the type of waterborne contaminant species. Thus, the overviews provided herein and elsewhere (Wilson 2014; Bhalkaran and Wilson 2016) reveal the utility of such biopolymeric flocculants for wider applications aimed at oxoanion removal in water and wastewater treatment.

\section{Treatment of cyanobacteria-contaminated water}

The proliferation of harmful cyanobacteria in river, lake and reservoir is a serious environmental issue because of cyanobacterial production of toxins, as well as taste and odor compounds that adversely affect aquatic ecosystems and humans (Schindler et al. 2012). Cyanobacteria threatens the safety of drinking water. Microcystins produced by Microcystis aeruginosa, which is the most notorious species in eutrophic surface waters, are hepatotoxins that pose a health threat for humans. Other algal organic matters could also compromise the safety of drinking water since they contain organic precursors leading to the development of
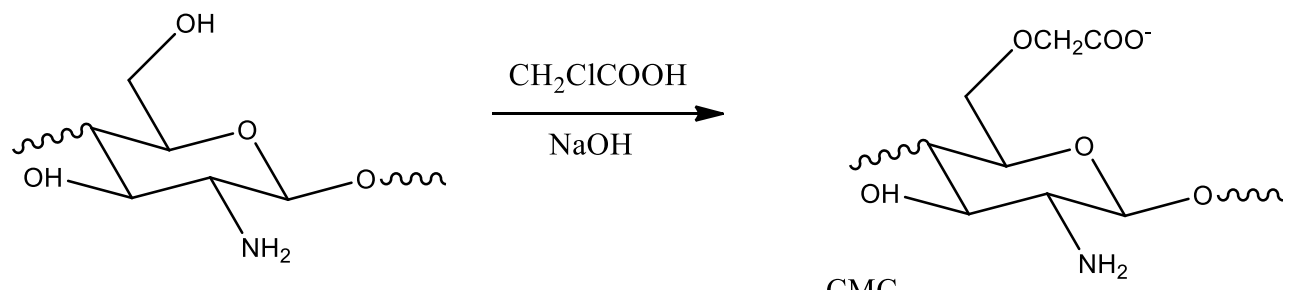

$\mathrm{CMC}$

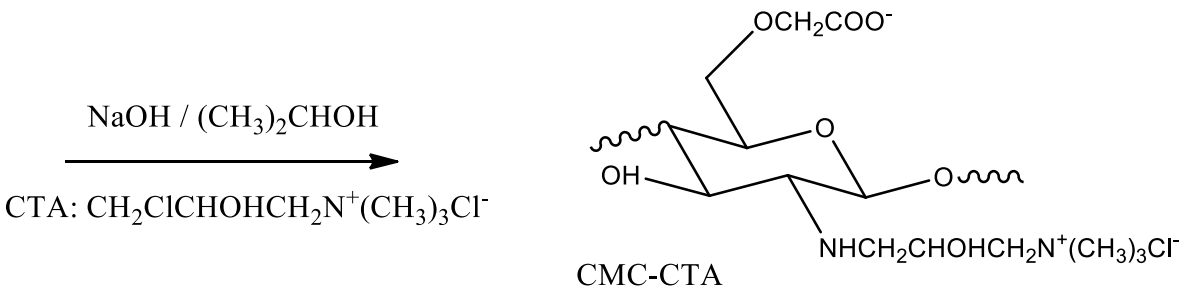

Scheme 1 Synthesis of carboxymethyl chitosan (CMC) and 3-chloro-2-hydroxypropyl trimethylammonium chloride grafted onto CMC (CTACMC) Adapted from Agbovi and Wilson (2018) 
Fig. 3 Effect of $\mathrm{pH}$ on the removal of orthophosphate $\mathrm{Pi}$ at variable flocculant dosage. a 3-chloro-2-hydroxypropyl trimethylammonium chloride grafted onto carboxymethyl chitosan, $\mathbf{b}$ chitosan and $\mathbf{c}$ carboxymethyl chitosan, where the initial concentration of $P_{\mathrm{i}}$ is $25 \mathrm{mg} / \mathrm{L}$. Reproduced with permission from Agbovi and Wilson (2018)
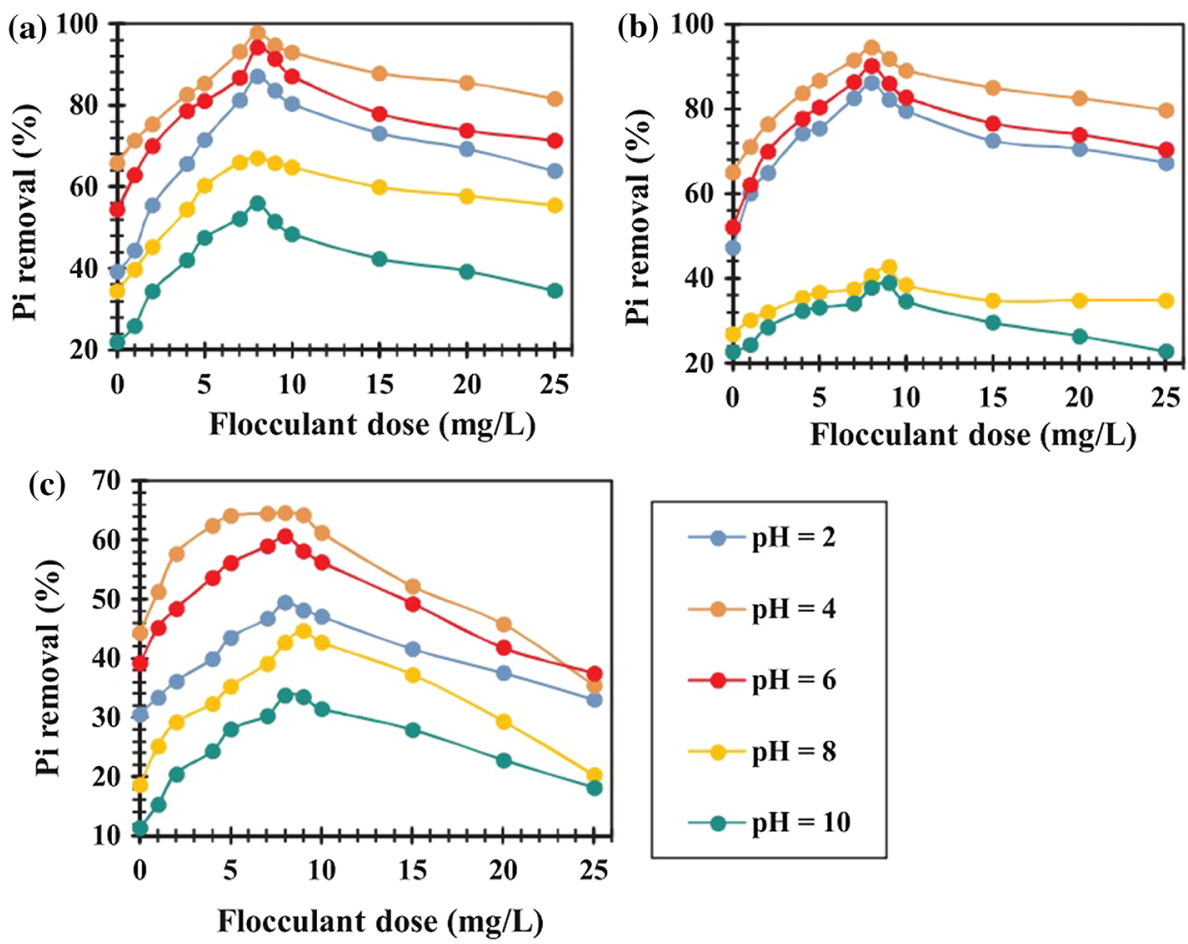

toxic disinfection by-products during chlorination. Generally, most algal organic matters including microcystins are contained within cyanobacteria cells, except Cylindrospermopsis raciborskii, which contains around $50 \%$ or less toxin in cells (Newcombe 2009). In other words, if toxins stay in cells, the process is safer because cells will be trapped in the precipitate, whereas if cell membranes are damaged, toxins will escape in the aqueous solution and, in turn, pollute the effluent discharged in natural waters. Therefore, an efficient method to remove cyanobacterial cells without damaging the membrane is significant to drinking water treatment.

Coagulation using conventional coagulants is the most important process for algal removal in conventional drinking water treatment due to the short detention time and low capital cost. Even though the traditional coagulants, such as polymeric aluminum and ferric chloride, can remove cyanobacteria cells without causing cell lysis (Xu et al. 2016), excess $\mathrm{Al}$ and Fe will lower water quality when plenty of traditional coagulant is used to remove cyanobacteria. Furthermore, the traditional coagulant is ineffective for the removal of extracellular microcystins. Recently, the increasing demand for environmental-friendly technologies has led to the search for natural, available and efficient materials to be used as coagulants. Chitosan, as a non-toxic and biodegradable coagulant/flocculant, has been extensively applied in water treatment and may be a suitable flocculant for cyanobacterial cells removal in drinking water treatment plants. For instance, Pei et al. (2014) studied the effects of chitosan on the treatment of cyanobacteria-laden source water. The results showed that chitosan can remove Microcystis aeruginosa cells efficiently without damaging the cells. In adition, chitosan can absorb extracellular microcystins due to the presence of amino and hydroxyl groups in chitosan, which give chitosan a powerful adsorptive capacity. The impacts of chitosan dosage and flocculation stirring were systematically investigated on Microcystis aeruginosa and microcystins removal. Under optimized conditions, i.e., chitosan concentration: $7.31 \mathrm{mg} / \mathrm{L}$, rapid mix speed: $227 \mathrm{rpm}$, rapid mix time: $2 \mathrm{~min}$, slow mix speed: $19 \mathrm{rpm}$, and slow mix time: $12 \mathrm{~min}, 99 \%$ of Microcystis aeruginosa cells and $46.5 \%$ microcystins were removed.

Although chitosan is relatively cheap and displays many suitable characterics for coagulation, the cost of chitosan is still high compared with traditional inorganic coagulants. To address issues of cost, research efforts were directed at finding ways to reduce the dosage of chitosan. Pan et al. (2006) prepared a composite coagulant containing chitosanmodified local soils (chitosan/soil $=1: 10$; weight). Results show that a loading of $0.025 \mathrm{~g} / \mathrm{L}$ chitosan-modified local soils removed $99 \%$ Microcystis aeruginosa cells (cell intensity $4.86 \times 10^{9}$ cells/L) within $16 \mathrm{~h}$ for a field enclosure of Taihu Lake. Pei et al. (2016) used a novel hydrogen-terminated porous Si wafer to enhance Microcystis aeruginosa removal by chitosan at a low dosage. It was found that moderate pre-oxidation by this wafer not only avoids the damage of Microcystis aeruginosa cell but also decreases the level of dissolved organic matter; hence, this led to a method for reducing the dosage of chitosan during coagulation. 
Table 5 Comparison of chitosan and chitosan derivatives for the removal of Microcystis aeruginosa cells. H-PSi Hydrogen-terminated porous $\mathrm{Si}$, CTSAC chitosan-aluminum chloride, HTCC chitosan quaternary ammonium salt

\begin{tabular}{|c|c|c|c|c|c|}
\hline Coagulant & Dose (mg/L) & $\begin{array}{l}\text { Cell den- } \\
\text { sity (cells/ } \\
\mathrm{mL})\end{array}$ & Advantage(s) & Problem(s) & References \\
\hline Chitosan & 7.31 & $2 \times 10^{6}$ & Degradability & Water insolubility & Pei et al. (2014) \\
\hline $\begin{array}{l}\text { Chitosan-modified local } \\
\text { soils (chitosan/soil 1:10; } \\
\text { weight) }\end{array}$ & 25 (chitosan dose: 2.27 ) & $4.86 \times 10^{6}$ & $\begin{array}{l}\text { Degradability; low dosage } \\
\text { of chitosan }\end{array}$ & $\begin{array}{l}\text { Water insolubility of } \\
\text { chitosan }\end{array}$ & Pan et al. (2006) \\
\hline $\begin{array}{l}\text { H-PSi wafer peroxide plus } \\
\text { chitosan }\end{array}$ & 0.75 & $2 \times 10^{6}$ & $\begin{array}{l}\text { Degradability; low dosage } \\
\text { of chitosan }\end{array}$ & $\begin{array}{l}\text { High cost of H-PSi wafer; } \\
\text { water insolubility of } \\
\text { chitosan }\end{array}$ & Pei et al. (2016) \\
\hline $\begin{array}{l}\text { CTSAC (chitosan/alu- } \\
\text { minum chloride 1:3; } \\
\text { weight) }\end{array}$ & 10.1 (chitosan dose: 2.6 ) & $2 \times 10^{6}$ & $\begin{array}{l}\text { Degradability; low dosage } \\
\text { of chitosan }\end{array}$ & $\begin{array}{l}\text { Water insolubility of } \\
\text { chitosan }\end{array}$ & Ma et al. (2016a) \\
\hline HTCC & 1.5 & $1 \times 10^{6}$ & $\begin{array}{l}\text { Degradability; water } \\
\text { solubility }\end{array}$ & High cost & Jin et al. (2017) \\
\hline
\end{tabular}

Another solution to reduce the dosage of chitosan during coagulation is to prepare a coagulant combining the advantages of bioflocculant with inorganic coagulant in water treatment. Ma et al. (2016a, b) studied the effect of a composite coagulant chitosan-aluminum chloride on removal of Microcystis aeruginosa cells in cyanobacteria-laden drinking water for treatment. Results showed that the composite coagulant can remove algal cells effectively for stronger entrapment and bridging ability, where negligible cell lysis was observed during the coagulation process. The optimal coagulation performance was obtained when the composite coagulant was set as $2.6 \mathrm{mg} / \mathrm{L}$ chitosan plus $7.5 \mathrm{mg} / \mathrm{L}$ aluminum chloride, under which $97.8 \%$ of intact cells, $53.1 \%$ of extracellular microcystins and almost all extracellular organic matters were simultaneously removed.

Even though the dosage of chitosan was reduced during coagulation as explained above, chitosan water insolubility-chitosan is soluble in weak acid solution-restricts its application in drinking water treatment processes. As a consequence, water-soluble chitosan derivatives have been synthesized recently. For example, Jin et al. (2017) studied the chitosan quaternary ammonium salt, a water-soluble chitosan derivative, for the removal of Microcystis aeruginosa cells during coagulation. Results show that Microcystis aeruginosa cells can be removed efficiently without damage under optimum coagulation conditions: coagulant dosage $1.5 \mathrm{mg} / \mathrm{L}$, rapid mixing for $0.5 \mathrm{~min}$ at $5.04 \mathrm{~g}$ and slow mixing for $30 \mathrm{~min}$ at $0.20 \mathrm{~g}$. Overall, as shown in Table 5, because chitosan and chitosan derivatives are non-toxic and biodegradable, they may be the promising coagulants for treatment of the cyanobacteria-laden source water. However, it is worth to note that their use for cyanobacterial removal is still at the laboratory research phase. A field pilot study on cyanobacteria removal by chitosan or chitosan derivatives should be done to obtain relevant operating parameters in the drinking water treatment plant. It will be helpful in this application to treat the cyanobacteria-containing source water in the drinking water treatment plant. In addition, cheaper and better performance chitosan derivatives should be developed in the future. This also contributes to the wide range of applications of chitosan derivatives in drinking water treatment plant.

\section{Sludge dewatering}

A major environmental problem facing wastewater treatment is the high volume of produced sludge during sewage treatment. Sludge dewatering, disposal and management are major challenges in the water industries, in particular to reduce the costs of final disposal and transportation. Typically, dewatering aims at reducing the weight and volume of the sludge. For this, the primary means of volume reduction is water removal. Depending on the operation and process used, sludge is usually a dilute suspension that generally contains a heterogeneous mixture of $50-80 \%$ of pollution in the form of a high-organic load, colloids, pathogenic germs, mineral particles, captions and metals (Zhai et al. 2012). As a consequence, if sludges are inadequately managed, they induce environmental pollution. Hence, the main target of sludge treatment is (1) to dewater as much as possible in the most economical way, (2) to eliminate smell by reducing the quantity of organic solids, and (3) to reduce the number of disease-causing microorganisms present in the solids. All such treatments are important for both economical and environmental reasons.

Sludge dewatering separates sludge into liquid and solid components for waste minimization. This requires an efficient conditioning step, and there are various technologies involving biological, chemical and/or physical treatments. Notewothy, after treatment, both the liquid and solid 
components may contain contaminations. Indeed, the dewatering step is not intended to clean the liquid of the sludge. Generally, chemical methods are used to enhance sludge filtration and final dewatering efficiency. Chemical methods involve the addition of, e.g., acids, alkalis, surfactants, coagulants and flocculants, to the sludge, in order to change its nature and to improve the dewatering performance. Coagulation/flocculation is commonly used for sludge conditioning when cost and efficiency are considered (Wei et al. 2018). During this treatment, sludge colloidal particles form large flocs and compacted cakes, which improve sedimentation and dewatering performance by increasing the sludge dewatering rates and solid content (Qi et al. 2011; Suopajärvi et al. 2013; Wei et al. 2018). The additives used can be classified into two main groups: mineral additives such as metal salts, and organic polymers of natural or synthetic origin. The synthetic polymers may be cationic, anionic or nonionic. In most cases, they are derived from oil-based and non-renewable raw materials (Suopajärvi et al. 2013). Some synthetic polymers often lead to secondary pollution and new environmental problems (Renault et al. 2009a). As a consequence, the sludge formed has a limited potential for recycling due to its non-biodegradability (Zahrim et al. 2011). Alternatively, natural polymers such as starches, celluloses and chitosan, and microbial materials such as bacteria, fungi and yeast, allow to reuse sludge as fertilizer and foster sludge proper handling and disposal (Bolto and Gregory 2007).

Depending on the nature of the solids to be treated, chemical conditioning can reduce the 90-99\% incoming moisture content to $65-85 \%$ (Yu et al. 2008). Moisture content in sludge directly corresponds to the dewatering extent. Other factors can be also be tuned, used such as the capillary suction time, in seconds, and the specific resistance in filtration, in $\mathrm{m} / \mathrm{kg}$ (Christensen and Dick 1985; Ripperger et al. 2012). These parameters are widely measured for evaluating sludge dewaterability. In a capillary suction time test, a filtration force generated by the capillary action of an absorbent filter paper is applied to the sample. The lower the capillary suction time, the higher the dewatering rate, i.e., the better sludge filtration properties. This test is simple, rapid and inexpensive because it does not require an external source of pressure or suction. The test of specific resistance in the filtration requires to be under vacuum. Noteworthy, the capillary suction time and the specific resistance in filtration are empirical parameters lacking accuracy. However, they rapidly provide an indication of a sample filtration capability, which is usually enough for operational controls.

Figures 4, 5, 6 and 7 show a typical example of results. The raw sludge originates from a municipal waste water treatment plant located at Beni-Messous, $15 \mathrm{~km}$ west of Algiers, Algeria. Sludge characteristics are described in Table 6. The following conditions were used: sludge

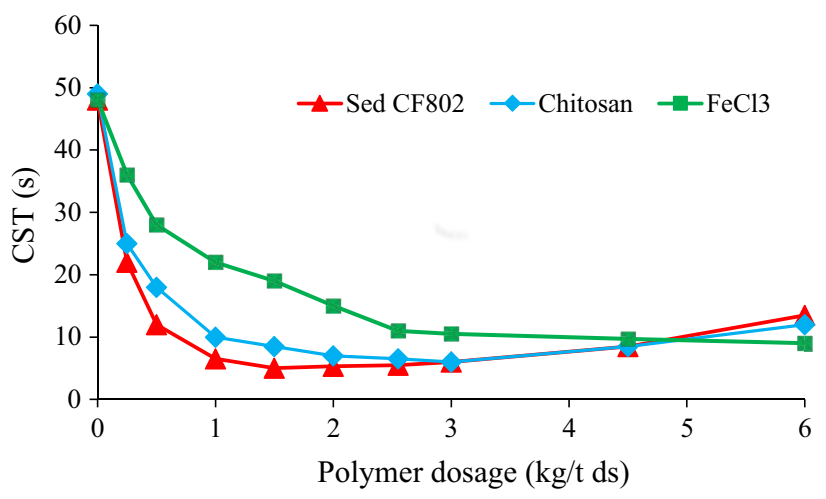

Fig. 4 Capillary suction time (CST) versus flocculant dosage. Flocculants: commercial cationic polymer Sedipur CF802 abbreviated Sed $\mathrm{CF} 802$, chitosan and ferric chloride $\mathrm{FeCl}_{3}$; the capillary suction time parameter was evaluated according to the Standard Method 2710G (APHA, AWWA and WEF 1995) with a portable apparatus (Triton 304B, chromatography paper Whatman $n^{\circ} 17$ )

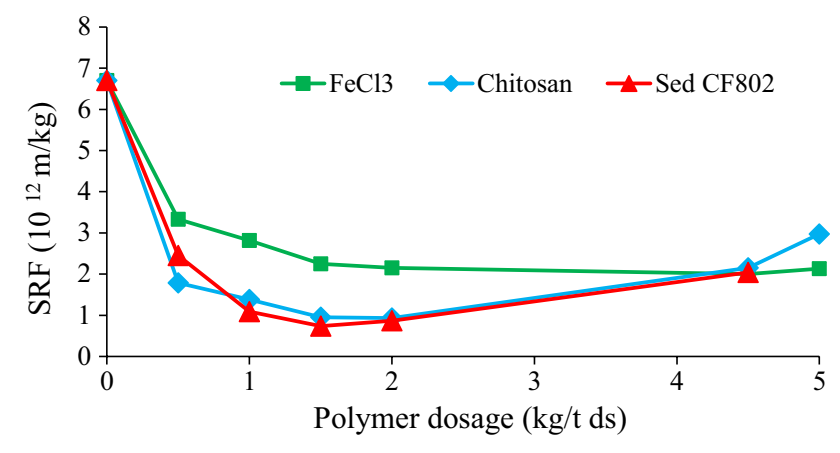

Fig. 5 Specific resistance to filtration (SRF) versus flocculant dosage. Flocculants: ferric chloride $\mathrm{FeCl}_{3}$, chitosan and a commercial cationic polymer Sedipur CF802 abbreviated Sed CF802

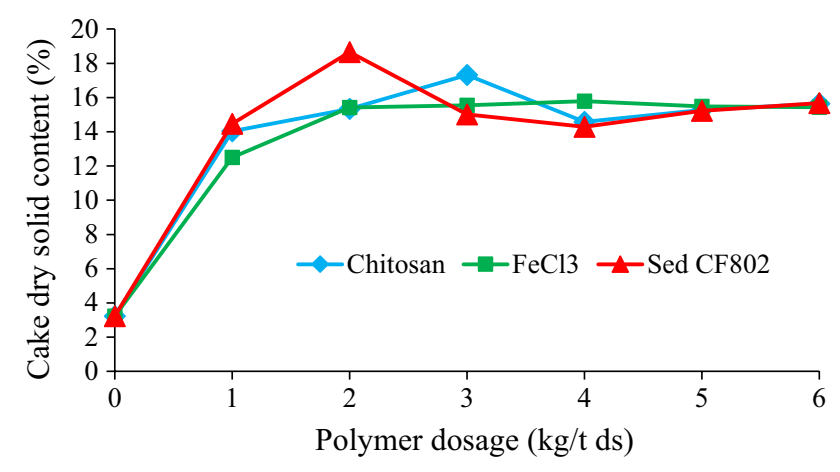

Fig. 6 Cake dry solid content versus flocculant dosage. Flocculants: chitosan, ferric chloride $\mathrm{FeCl}_{3}$ and a commercial cationic polymer Sedipur CF802 abbreviated Sed CF802

conditioning was carried out by flocculation using a conventional jar test with six ramps; samples of $100 \mathrm{~mL}$ in a 500$\mathrm{mL}$ beaker were mixed with solutions containing different 


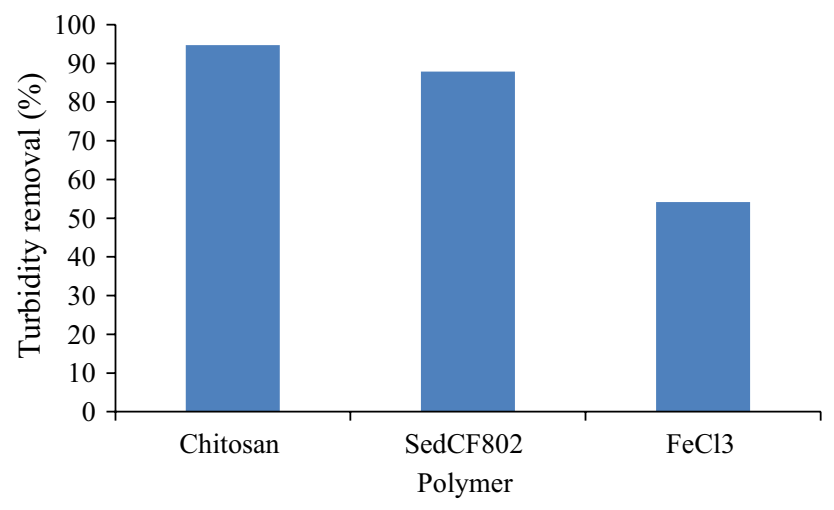

Fig. 7 Turbidity removal versus flocculant dosage. Flocculants: chitosan, a commercial cationic polymer Sedipur CF802 abbreviated Sed $\mathrm{CF} 802$ and chloride $\mathrm{FeCl}_{3}$

Table 6 Characteristics of raw sludge before conditioning

\begin{tabular}{lll}
\hline Parameters & Unit & Value \\
\hline $\mathrm{pH}$ & & 8.3 \\
Total suspended solids & $\mathrm{g} / \mathrm{L}$ & 3.3 \\
Volatile suspended solids & $\mathrm{g} / \mathrm{L}$ & 17 \\
Dry solid content & $\%$ & 3.22 \\
Capillary suction time & $\mathrm{s}$ & 48 \\
Specific resistance to filtration & $10^{12} \mathrm{~m} / \mathrm{kg}$ & 6.78 \\
Temperature & ${ }^{\circ} \mathrm{C}$ & 25 \\
\hline
\end{tabular}

amounts of conditioners, calculated on the basis of chemical mass per unit mass of dry solids contents of the sludge (expressed in kilogram per ton of dry solids); the jar test was operated at $140 \mathrm{rpm}$ for $20 \mathrm{~s}$ for intense mixing of the polyelectrolyte into the sludge, and then, stirring speed was reduced to $28 \mathrm{rpm}$ for $2 \mathrm{~min}$ to promote floc growth. Dewatering sludge was processed using a standardized, laboratory-scale, pressure filtration cell (APHA, AWWA and WEF 1995). After flocculation, conditioned sludge is immediately transferred into the filtration cell. An appropriate pressure of $10 \mathrm{~kg} / \mathrm{cm}^{2}$ was applied. During the introduction of the piston, a certain amount of filtrate can flow under the effect of gravity without pressing. The filtration time was set to $1 \mathrm{~h}$. Collected filtrates were measured as function of time. Dry solids content (ds in \%) of the cake, and filtrate turbidity were determined according to procedures given in Standard Methods (APHA, AWWA and WEF 1995). Chitosan efficiency was compared to synthetic cationic polymer Sedipur CF802 abbreviated Sed CF802, and ferric chloride $\mathrm{FeCl}_{3}$.

The capillary suction time is an empirical measure of the resistance applied by the sludge to the withdrawal of water. In Fig. 4, the results show that the capillary suction time has been reduced from $48 \mathrm{~s}$ in the raw sludge to $5 \mathrm{~s}$ and $6 \mathrm{~s}$ with optimal dosage, in the range of $2-3$ and $1.5-3 \mathrm{~kg} / \mathrm{t} \mathrm{ds}$ of Sed CF802 and chitosan, respectively. Beyond the optimal dosage, the capillary suction time increases again. Also, with sludge conditioned with $6 \mathrm{~kg} / \mathrm{t}$ ds as optimal dose of $\mathrm{FeCl}_{3}$, capillary suction time was around $9 \mathrm{~s}$. Indeed, the two cationic polyelectrolytes showed a good dewaterability. The low capillary suction time obtained using cationic polyelectrolytes is due to smaller flocs and sludge containing less bound water. The sludges are therefore dewatered faster than those obtained with $\mathrm{FeCl}_{3}$. However, further increase in polyelectrolyte concentration increased the capillary suction time. This is associated with the overdosing phenomena caused by excess polyelectrolyte remaining in the liquid phase leading to the viscosity increase and then deteriorating the sludge dewaterability (Christensen et al. 1985). Otherwise, saturation of the colloidal surface with polymer is usually accompanied by a reversal of the surface charge. The optimal polymer dosage is commonly associated with partial coverage of the colloidal surface, accompanied by a minimum surface charge (Lee and Liu 2000).

Figure 5 depicts the evolution of specific resistance in filtration data as a function of dosage of each flocculant. Initially, the specific resistance in filtration value of unconditioned sludge was $6.78 \times 10^{12} \mathrm{~m} / \mathrm{kg}$. The value decreased when both cationic polyelectrolytes and $\mathrm{FeCl}_{3}$ were added. The optimum doses for Sed CF802 and chitosan were about $1.5-2 \mathrm{~kg} / \mathrm{t}$ ds for both polyelectrolytes. Beyond the optimum value, the SRF increased again. SRF values of sludge conditioned with Sed CF802 and chitosan at the respective optimum doses were $0.634 \times 10^{12} \mathrm{~m} / \mathrm{kg}$ and $0.932 \times 10^{12} \mathrm{~m} /$ $\mathrm{kg}$, respectively. On the other hand, $4.5 \mathrm{~kg} / \mathrm{t} \mathrm{ds}$ of $\mathrm{FeCl}_{3}$ has reduced specific resistance in filtration to $2 \times 10^{12} \mathrm{~m} /$ $\mathrm{kg}$. Through these results, the objective of this study was accomplished; adding flocculating agents improved the dewaterability of sludge, i.e., reduced the specific resistance in filtration. Chitosan as well as Sed CF802 and $\mathrm{FeCl}_{3}$ helped to increase the sludge particle size by agglomerating the small fines of the sludge colloids, causing blinding, and to form large flocs, which are easily separated from the water. Flocs agglomeration is explained by the specific resistance in filtration decrease and consequently the filterability improvement.

The evolution of the cake dryness according to the dose of each flocculant is presented in Fig. 6. A significant increase in dryness to $17.31 \%$ with $3 \mathrm{~kg} / \mathrm{t}$ ds of chitosan has been recorded, and $2 \mathrm{~kg} / \mathrm{t}$ ds of Sed CF802 increased cake dryness to $18.65 \%$. The cakes formed with application of both polyelectrolytes were uniform, with the thicknesses of $0.5 \mathrm{~cm}$. These results led to the conclusion that the performances of these two polymers were similar. Also, $15.78 \%$ of cake dryness was obtained using $4 \mathrm{~kg} / \mathrm{t}$ ds of $\mathrm{FeCl}_{3}$. Obtaining large flocs after flocculation was related to good settleability and filterability. However, the filterability did not depend on the size of the flocs. Filterability depended mainly on 
floc cohesion or their mechanical and bond strengths uniting the elementary particles that made up the formed cluster. The weakness of these links may result in a change of the structure of the filter cake, which becomes less porous, and consequently decreases the rate of filtration.

Figure 7 depicts the filtrate turbidity after filtration tests of flocculated sludges with different polymers. It shows that chitosan and Sed CF802 remove $94.68 \%$ and $87.85 \%$ of the turbidity, respectively, resulting in a maximum filtrate cleaning with minimum nephelometric turbidity unit, and NTU values. $54.18 \%$ of turbidity abatement has been obtained using $\mathrm{FeCl}_{3}$. A better capture efficiency of some fine dispersed particles in the aqueous phase is related to the lower residual turbidity of filtrate when both cationic polyelectrolytes were used. These fine, dispersed particles of sludge were flocculated to form primary flocs due to electrostatic attraction. Lee and Liu (2000) have shown that the fine particles should cause a decrease of cake porosity, and flocculation of sludge particles by the cationic polyelectrolyte could prevent fine particles from clogging up the filter. This also contributes to the enhanced dewaterability of sludge.

Sludge particles are most frequently positively or negatively charged. Chemical conditioners, often bearing opposite charges, are used to coagulate or flocculate sludge colloids by charge neutralization, leading to the establishment of interactions between charged particles. The two main mechanisms of flocculation using organic polymers are the destabilization of the colloidal system by charge neutralization and the bridging of particles. Polymers adsorb on the surface of colloidal particles by chemical strength (chemical bonding) or physical forces, e.g., van der Waals forces, or both. The non-adsorbed side of polymers can then reach another particle to form a particle-particle bridge. Therefore, destabilization of sludge is explained by charge neutralization and/or particles bridging during the application of polyelectrolytes. The combined action of the mass and charge of the polymer helps to implement both bridging and charge neutralization (Gregory and Barany 2011). The bridges allows the polymer to get a large number of particles and to include particles into large flocks. Since chitosan is a cationic polyelectrolyte, in our case, the clotting mechanism is essentially done by a double effect: charge neutralization and bridging flocs. Chitosan is adsorbed on the surface of colloidal particles by attractive electrostatic interactions between the negative charges of the surface of the colloidal particles and the amine groups of the chitosan (Renault et al. 2009a, b). These electrostatic interactions also promote adsorption (Gregory and Barany 2011), which explains the fact that the adsorbed amount of chitosan increases with the concentration of added chitosan.

Results on the effect of the chitosan dose show that increasing chitosan levels above its optimum concentration induces higher specific resistance in filtration and lower content of cake dry solids. This phenomenon could be explained by the reversal of load and re-stabilization of colloidal particles that have been coagulated. This restabilization of loads depends on the zeta potential of the solution (Gregory and Barany 2011). In fact, chitosan, by its constitution, has a surplus of electrical charges and is solvated by water trapping colloidal particles, thus causing turbidity. Indeed, these authors have reported that the excessive addition of polymer creates hyperconductive water where collisions between particles due to electric forces are intense; they disrupt completely the balance of the solution (Gregory and Barany 2011).

In conclusion, compared to a commercial synthetic polymer, chitosan has shown the same efficiency in terms of sludge conditioning. Chitosan, as a natural organic flocculant, may be a promising substitute for conventional flocculants used so far in the field of sludge conditioning. The sole drawback of chitosan is its relatively high cost, which could be minimized by future technological developments.

\section{Post-treatment of sanitary landfill leachate}

Landfill leachates have high concentrations of ammonia nitrogen, biodegradable organic matter, recalcitrant compounds such as humic substances, heavy metals and xenobiotic organic compounds (Kjeldsen et al. 2002). A biological treatment is commonly used to remove the bulk of biodegradable organic matter and ammonia nitrogen, due to its reliability, simplicity and high cost-effectiveness. As a complement to the biological treatment, the coagulation-flocculation process has been employed to reduce the concentration of recalcitrant organic matter and toxicity of the landfill leachate (Renou et al. 2008; Ziyang et al. 2009). Nevertheless, chemical coagulants may have adverse effects on the environment. Hence, it is suggested that chitosan could be a better alternative (Verma et al. 2012; Ramli and Aziz 2015; Nascimento et al. 2016).

Nascimento et al. (2016) carried out a determination of the optimum dosage and $\mathrm{pH}$ values for coagulation-flocculation of biologically treated leachate using chitosan as biocoagulant for the removal of recalcitrant organic matter. The performance of chitosan was compared to aluminum sulfate, which is a metal coagulant widely used in wastewater treatment plants. The coagulant dosage investigated ranged from 700 to $1100 \mathrm{mg} / \mathrm{L}$ for chitosan and from 1300 to $1700 \mathrm{mg} / \mathrm{L}$ for alum; the $\mathrm{pH}$ value varied from 6.0 to 9.0 for chitosan and from 8.0 to 10.0 for alum. The gradient for rapid mixing, time for rapid mixing, gradient for flocculation mixing and flocculation time were held constant. Their values for chitosan and alum were $400 \mathrm{~s}^{-1}$ and $869 \mathrm{~s}^{-1}$ (gradient for rapid mixing), $30 \mathrm{~s}$ and $10 \mathrm{~s}$ (time for rapid mixing), $30 \mathrm{~s}^{-1}$ and $30 \mathrm{~s}^{-1}$ (gradient for flocculation) and $10 \mathrm{~min}$ and $10 \mathrm{~min}$ (flocculation time), respectively. Based on a mathematical 
model and graphical optimization, the results showed that chitosan dosages below $700 \mathrm{mg} / \mathrm{L}$ and $\mathrm{pH}$ values between 6.0 and 6.5 or chitosan dosage near $900 \mathrm{mg} / \mathrm{L}$ and $\mathrm{pH}$ values between 8.0 and 8.5 , lead to greater removal efficiencies of recalcitrant organic matter (50 to $80 \%$ ); the highest turbidity removal (90\%) was obtained at a lower dosage, less than $900 \mathrm{mg} / \mathrm{L}$, with a $\mathrm{pH}$ between 6.5 and 9.5 ; and an alum dosage between 1542 and $1762 \mathrm{mg} / \mathrm{L}$ with a pH between 8.5 and 10.0 leads to greater removal efficiency values. Employing the response optimizer function (Minitab ${ }^{\circledR} 16$ software), the maximum efficiency removal of true color $(80 \%)$ and the turbidity removal $(91 \%)$ were found using $960 \mathrm{mg} / \mathrm{L}$ of chitosan at $\mathrm{pH} 8.5$; and using $1610 \mathrm{mg} / \mathrm{L}$ of alum at $\mathrm{pH} 9.5$, the true color removal efficiency was $87 \%$ and the turbidity removal reached $81 \%$ (Nascimento et al. 2016). The authors explained that with decreasing solution $\mathrm{pH}$, part of the humic substances in the leachate became insoluble, resulting in a reduced level of remaining organic matter. Consequently, the amount of chitosan required for destabilization of the colloidal system is lower. Moreover, at a $\mathrm{pH}$ of 6.0 or less, more than $90 \%$ of the amine groups are protonated. Thus, a lower dosage of chitosan is required for efficient coagulation-flocculation at lower $\mathrm{pH}$. This can be explained by the acid-base properties of chitosan and the degree of dissociation of the polyelectrolyte (Guibal and Roussy 2007). The $p K_{\mathrm{a}}$ of the amine groups is close to 6.3-6.4 for the fully dissociated chitosan with a deacetylation degree of close to $90 \%$. The authors concluded that the high sensitivity of the performance of chitosan in removing true color and turbidity levels opens up possibilities for chitosan use as a coagulant to aid in the removal of recalcitrant contaminants in landfill leachate.

\section{Conclusion}

Chitosan, a partially deacetylated polysaccharide obtained from chitin, has received considerable attention in recent years as a versatile bioflocculant. Its potential application as an efficient and eco-friendly material for environmental purposes has been well investigated. Chitosan can be used for water and wastewater treatment, sludge dewatering and post-treatment of sanitary landfill leachate. In general, the data published have shown comparable or better flocculation efficiency compared to the current commercial flocculants, and thus, chitosan has strong potential in the near future. Although its performance was satisfactory and pilot plants were designed, the economic feasibility to design large-scale treatment plants still needs to be carried out. Special attention should be given to investigating the intrinsic characteristics of the chitosan biopolymer, i.e., degree of deacetylation and molecular weight, and of the various operating parameters, e.g., dosage, initial $\mathrm{pH}$, settling time, etc. In addition, more research is still needed to understand the mechanisms of flocculation in order to control flocs density and removal ability of pollutants.

\section{References}

Abebe LS, Chen XY, Sobsey MD (2016) Chitosan coagulation to improve microbial and turbidity removal by ceramic water filtration for household drinking water treatment. Int J Environ Res Public Health 13:3. https://doi.org/10.3390/ijerph1303 0269

Agbovi HK, Wilson LD (2017) Flocculation optimization of orthophosphate with $\mathrm{FeCl}_{3}$ and alginate using the BoxBehnken response surface methodology. Ind Eng Chem Res 56:3145-3155. https://doi.org/10.1021/acs.iecr.6b04765

Agbovi HK, Wilson LD (2018) Design of amphoteric chitosan flocculants for phosphate and turbidity removal in wastewater. Carbohydr Polym 189:360-370. https://doi.org/10.1016/j.carbp ol.2018.02.024

Agbovi HK, Wilson LD, Tabil LG (2017) Biopolymer flocculants and oat hull biomass to aid the removal of orthophosphate in wastewater treatment. Ind Eng Chem Res 56:37-46. https://doi. org/10.1021/acs.iecr.6b04092

Ahmad AL, Sumathi S, Hameed BH (2005a) Adsorption of residue oil from palm oil mill effluent using powder and flake chitosan: equilibrium and kinetic studies. Water Res 39:2483-2494. https://doi.org/10.1016/j.watres.2005.03.035

Ahmad AL, Sumathi S, Hameed BH (2005b) Residual oil and suspended solid removal using natural adsorbents chitosan, bentonite and activated carbon: a comparative study. Chem Eng J 108:179-185. https://doi.org/10.1016/j.cej.2005.01.016

Ahmad AL, Sumathi S, Hameed BH (2006) Coagulation of residue oil and suspended solid in palm oil mill effluent by chitosan, alum and PAC. Chem Eng J 118:99-105. https://doi. org/10.1016/j.cej.2006.02.001

Altaher H (2012) The use of chitosan as a coagulant in the pretreatment of turbid sea water. J Hazard Mater 233-234:97-102. https://doi.org/10.1016/j.jhazmat.2012.06.061

APHA, AWWA and WEF (1995) Standard methods for the examination of water and wastewater, 19th edition. American Public Health Association, American Water Works Association, Water Environment Federation. Washington, DC, pp 2-54

Bala JD, Lalung J, Ismail N (2015) Studies on the reduction of organic load from palm oil mill effluent (POME) by bacterial strains. Int J Recycl Org Waste Agric 4:1-10. https://doi. org/10.1007/s40093-014-0079-6

Banu RJ, Do KU, Yeom IT (2007) Phosphorus removal in low alkalinity secondary effluent using alum. Int J Environ Sci Technol 5:93-98. https://doi.org/10.1007/BF03326001

Bello MM, Raman AAA (2017) Trend and current practices of palm oil mill effluent polishing: application of advanced oxidation processes and their future perspectives. J Environ Manag 198:170-182. https://doi.org/10.1016/j.jenvman.2017.04.050

Bello MM, Nourouzi MM, Abdullah LC, Choong TS, Keshani S (2013) POME is treated for removal of color from biologically treated POME in fixed bed column: applying wavelet neural network (WNN). J Hazard Mater 262:106-113. https:// doi.org/10.1016/j.jhazmat.2013.06.053

Besse V, Illy N, David G, Caillol S, Boutevin B (2016) A chitosan derivative containing both carboxylic acid and quaternary ammonium moieties for the synthesis of cyclic carbonates. 
ChemSusChem 9:2167-2173. https://doi.org/10.1002/ cssc. 201600499

Bhalkaran S, Wilson LD (2016) Investigation of self-assembly processes for chitosan-based coagulant-flocculant systems: a minireview. Int J Mol Sci 17:1662. https://doi.org/10.3390/ijms1 7101662

Bolto B, Gregory J (2007) Organic polyelectrolytes in water treatment. Water Res 41:2301-2324. https://doi.org/10.1016/j.watre s.2007.03.012

Bratby J (1980) Coagulation and flocculation. Uplands Press Ltd, Croydon, p 354

Bratby J (2006) Coagulation and flocculation in water and wastewater treatment, 2nd edn. IWA Publishing, London, p 450. ISBN: 13:9781843391067

Chan YJ, Chong MF, Law CL (2011) Optimization on thermophilic aerobic treatment of anaerobically digested palm oil mill effluent (POME). Biochem Eng J 55:193-198. https://doi.org/10.1016/j. bej.2011.04.007

Chen J, Luan Z (2010) Enhancing phosphate removal by coagulation using polyelectrolytes and red mud. Fresenius Environ Bull 19:2200-2204. https://doi.org/10.1016/S0304-3894(03)00070-0

Chong MF (2012) Direct flocculation process for wastewater treatment. In: Sharma SK, Sanghi R (eds) Advances in water treatment and pollution prevention, vol 8. Springer, Dordrecht, pp 201-230. ISBN 978-94-007-4203-1

Christensen GL, Dick RI (1985) Specific resistance measurements: methods and procedures. J Environ Eng 111:258-271

Christensen J, Sørensen P, Christensen G, Hansen J (1985) Mechanisms for overdosing in sludge conditioning. J Environ Eng 119:159-171

Cox M, Négré P, Yurramendi L (2007) Industrial liquid effluents. San Sebastian: INASMET Tecnalia, pp 283. ISBN: 84-95520-14-1

Crini G (2015) Non-conventional adsorbents for dye removal. In: Sharma SK (ed) green chemistry for dyes removal from wastewater. Scrivener Publishing LLC, Beverly, pp 359-407. ISBN 978-1-118-72099-8

Crini G, Badot PM (eds) (2007) Traitement et épuration des eaux industrielles polluées. PUFC Press, Besançon, p 352. ISBN: 978-2-84867-197-0

Crini G, Badot PM, Morin-Crini N (2009a) Traitement des eaux par du chitosane: intérêts, méthodes et perspectives. Techniques de l'Ingénieur RE-126, pp 1-13

Crini G, Badot PM, Guibal E (eds) (2009b) Chitine et chitosane - du biopolymère à l'application. Besançon: PUFC Press, France, $p$ 303. ISBN: 978-2-84867-249-6

Crini G, Torri G, Lichtfouse É, Kyzas GZ, Wilson LD, Morin-Crini N (2019) Cross-linked chitosan hydrogels for dye removal. In: Crini G, Lichtfouse É (eds) Chitin and chitosan-applications in food, agriculture, pharmacy, medicine and wastewater treatment. Sustainable agriculture reviews 35. Springer, Berlin, chapter 10. https://doi.org/10.1007/978-3-030-16581-9_10

de Alvarenga ES (2011) Characterization and properties of chitosan. In: Elnashar M (ed) Biotechnology of biopolymers. InTech, Rijeka, chapter 5, pp 91-108. https://doi.org/10.5772/17020

Desbrières J, Guibal E (2018) Chitosan for wastewater treatment. Polym Int 67:7-14. https://doi.org/10.1002/pi.5464

Ding GT, Yaakob Z, Takriff MS, Salihon J, Rahaman MSA (2016) Biomass production and nutrients removal by a newly-isolated microalgal strain Chlamydomonas $s p$ in palm oil mill effluent (POME). Int J Hydrog Energy 41:4888-4895. https://doi. org/10.1016/j.ijhydene.2015.12.010

Domard A, Domard M (2001) Chitosan: Structure-properties relationship and biomedical applications. In: Severian D (ed) polymeric biomaterials. Marcel Dekker, New York, pp 187-212
Dunets CS, Zheng Y (2015) Combined precipitation/flocculation method for nutrient recovery from greenhouse wastewater. HortScience 50:921-926

Dutta PK, Dutta J, Tripathi VS (2004) Chitin and chitosan: chemistry, properties and applications. J Sci Ind Res 63:20-31

Fierro S, Del Pilar Sánchez-Saavedra M, Copalcúa C (2008) Nitrate and phosphate removal by chitosan immobilized Scenedesmus. Bioresour Technol 99:1274-1279. https://doi.org/10.1016/j.biort ech.2007.02.043

Filipkowska U, Jóźwiak T, Szymczyk P (2014) Application of crosslinked chitosan for phosphate removal from aqueous solutions. Prog Chem Appl Chitin Deriv 19:5-14

Ghimici L, Brunchi CE, Diaconu A (2016) Removal of some commercial pesticides containing $\alpha$-cypermethrin, deltamethrin and mancozeb as active ingredients by chitosan solution. Cellulose 23:3837-3846

Goosen MFA (ed) (1997) Applications of chitin and chitosan. CRC Press LLC, Boca Raton, p 336. ISBN13: 9781566764490

Gregory J, Barany S (2011) Adsorption and flocculation by polymers and polymer mixtures. Adv Colloid Int Sci 169:1-12. https://doi. org/10.1016/j.cis.2011.06.004

Guibal E, Roussy J (2007) Coagulation and flocculation of dye-containing solutions using a biopolymer (chitosan). React Funct Polym 67:33-42. https://doi.org/10.1016/j.reactfunctpolym.2006.08.008

Jin Y, Pei HY, Hu WR, Zhu YW, Xu HZ, Ma CX, Sun JM, Li HM (2017) A promising application of chitosan quaternary ammonium salt on Microcystis aeruginosa cells removal in drinking water. Sci Total Environ 583:496-504

Kadokawa JI (2018) Enzymatic preparation of functional polysaccharide hydrogels by phosphorylase catalysis. Pure Appl Chem 90:1045-1054. https://doi.org/10.1515/pac-2017-0802

Kanmani P, Aravind J, Kamaraj M, Sureshbabu P, Karthikeyan S (2017) Environmental applications of chitosan and cellulosic biopolymers: a comprehensive outlook. Bioresour Technol 242:295-303. https://doi.org/10.1016/j.biortech.2017.03.119

Kjeldsen P, Barlaz MA, Rooker AP, Baun A, Ledin A, Christensen T (2002) Present and long-term composition of MSW landfill leachate: a review. Environ Sci Technol 32:297-336. https://doi. org/10.1080/10643380290813462

Kurita K (1998) Chemistry and application of chitin and chitosan. Polym Degrad Stab 59:117-120. https://doi.org/10.1016/S0141 $-3910(97) 00160-2$

Kurita K (2006) Chitin and chitosan: functional biopolymers from marine crustaceans. Mar Biotechnol 8:203-226. https://doi. org/10.1007/s10126-005-0097-5

Laamanen CA, Ross GM, Scott JA (2016) Flotation harvesting of microalgae. Renew Sustain Energy Rev 58:75-86. https://doi. org/10.1016/j.rser.2015.12.293

Latifian M, Liu J, Mattiasson B (2014) Recovery of struvite via coagulation and flocculation using natural compounds. Environ Technol 35:2289-2295. https://doi.org/10.1080/09593 330.2014 .902110

Lee CH, Liu JC (2000) Enhanced sludge dewatering by dual polyelectrolytes conditioning. Water Res 34:4430-4436. https:// doi.org/10.1016/S0043-1354(00)00209-8

Lee CS, Robinson J, Chong MF (2014) A review on application of flocculants in wastewater treatment. Proc Saf Environ Prot 92:489-508. https://doi.org/10.1016/j.psep.2014.04.010

Levine NM (1981) Natural polymer sources. In: Schwoyer WLK (ed) Polyelectrolytes for water and wastewater treatment. CRC Press, Boca Raton, pp 47-60. ISBN13: 978-0849354397

Li CB, Hein S, Wang K (2008) Biosorption of chitin and chitosan. Mater Sci Technol 24:1088-1099. https://doi. org/10.1179/17438408X341771

Lichtfouse E, Morin-Crini N, Fourmentin M, Zemmouri H, do Carmo Nascimento IA, Queiroz LM, Mohd Tadza MY, Picos-Corrales 
LA, Pei H, Wilson LD, Crini G (2019) Chitosan for direct bioflocculation processes. In: Crini G, Lichtfouse E (eds) Chitin and chitosan-applications in food, agriculture, pharmacy, medicine and wastewater treatment. Sustainable Agriculture Reviews 35, Springer, Switzerland 2019, chapter 9. https://doi. org/10.1007/978-3-030-16581-9_9

Ma CX, Pei HY, Hu WR, Cheng J, Xu HZ, Jin Y (2016a) Significantly enhanced dewatering performance of drinking water sludge from a coagulation process using a novel chitosanaluminum chloride composite coagulant in the treatment of cyanobacteria-laden source water. RSC Adv 6:61047-61056. https://doi.org/10.1039/c6ra11989a

Ma CX, Hu WR, Pei HY, Xu HZ, Pei RT (2016b) Enhancing integrated removal of Microcystis aeruginosa and adsorption of microcystins using chitosan-aluminum chloride combined coagulants: effect of chemical dosing orders and coagulation mechanisms. Colloid Surf A 490:258-267

Meera GT, Emilia A (2006) Polyionic hydrocolloids for the intestinal delivery of protein drugs: alginate and chitosan-a review. J Control Release 114:1-14. https://doi.org/10.1016/j.jconr el.2006.04.017

Morin-Crini N, Crini G (eds) (2017) Eaux industrielles contaminées. Besançon: PUFC Press, France, p 513. ISBN: 978-2-84867-589-3

Morin-Crini N, Lichtfouse É, Torri G, Crini G (2019) Fundamentals and applications of chitosan. In: Crini G, Lichtfouse É (eds) Chitin and chitosan-history, fundamentals and innovations. Sustainable Agriculture Reviews 35, Springer, Switzerland AG 2019, chapter 2. https://doi.org/10.1007/978-3-030-16538-3_2

MPOB (2012) Overview of the Malaysian oil palm industry 2011. Shah Alam Econ Ind Dev Div. http://palmoilis.mpob.gov.my/ index.php/overview-of-industry/224-overview-of-industry-2011

Muzzarelli RAA (1973) Natural chelating polymers. Pergamon Press, Oxford

Muzzarelli RAA (1988) Carboxymethylated chitins and chitosans. Carbohydr Polym 8:1-21. https://doi.org/10.1016/01448617(88)90032-X

Nascimento IOC, Guedes ARP, Perelo LW, Queiroz LM (2016) Posttreatment of sanitary landfill leachate by coagulation-flocculation using chitosan as primary coagulant. Water Sci Technol 74:246255. https://doi.org/10.2166/wst.2016.203

Nechita P (2017) Applications of chitosan in wastewater treatment. In: Shalaby EA (ed) Biological activities and application of marine polysaccharides. InTech, Rijeka, chapter 10, pp 209-228. https ://doi.org/10.5772/65289

Newcombe G (ed) (2009) International guidance manual for the management of toxic cyanobacteria. Global water research coalition and water quality research Australia, London

No HK, Meyers SP (1995) Preparation and characterization of chitin and chitosan-a review. J Aquat Food Prod Technol 4:27-52. https://doi.org/10.1300/J030v04n02_03

No HK, Meyers SP (2000) Application of chitosan for treatment of wastewaters. Rev Environ Contam Toxicol 63:1-28. https://doi. org/10.1007/978-1-4757-6429-1_1

Nwe N, Furuike T, Tamura H (2011) Chitosan from aquatic and terrestrial organisms and microorganisms. Production, properties and applications. In: Johnson BM, Berkel ZE (eds) Biodegradable materials. Nova Science Publishers, Inc., Hauppauge, chapter 2, pp 29-50

Oladoja NA (2015) Headway on natural polymeric coagulants in water and wastewater treatment operations. J Water Proc Eng 6:174192. https://doi.org/10.1016/j.jwpe.2015.04.004

Pakdel PR, Peighambardoust SJ (2018) Review on recent progress in chitosan-based hydrogels for wastewater treatment application. Carbohydr Polym 201:264-279. https://doi.org/10.1016/j.carbp ol.2018.08.070
Pambi RLL, Musonge P (2015) The efficiency of chitosan as a coagulant in the treatment of the effluents from the sugar industry. $\mathrm{J}$ Polym Mater 32:57-63

Pan G, Zou H, Chen H, Yuan X (2006) Removal of harmful cyanobacterial blooms in Taihu Lake using local soils. III. Factors affecting the removal efficiency and an in situ field experiment using chitosan-modified local soils. Environ Pollut 141:206-212

Parthasarathy S, Gomes RL, Manickam S (2016) Process intensification of anaerobically digested palm oil mill effluent (AADPOME) treatment using combined chitosan coagulation, hydrogen peroxide $\left(\mathrm{H}_{2} \mathrm{O}_{2}\right)$ and Fenton's oxidation. Clean Technol Environ Policy 18:219-230. https://doi.org/10.1007/s1009 8-015-1009-7

Pei HY, Ma CX, Hu WR, Sun F (2014) The behaviors of Microcystis aeruginosa cells and extracellular microcystins during chitosan flocculation and flocs storage processes. Bioresour Technol 151:314-322

Pei HY, Xu HZ, Xiao HD, Sun JM, Hu WR, Li XQ, Ma CX, Jin Y (2016) Using a novel hydrogen-terminated porous $\mathrm{Si}$ wafer to enhance Microcystis aeruginosa effective removal by chitosan at a low dosage. Colloid Surf A 499:88-96

Peters MG (1995) Applications and environmental aspects of chitin and chitosan. J Macromol Sci Part A Pure Appl Chem A32:629-640. https://doi.org/10.1080/10601329508010276

Prado HJ, Matulewicz MC (2014) Cationization of polysaccharides: a path to greener derivatives with many industrial applications. Eur Polym J 52:53-75. https://doi.org/10.1016/j.eurpo lymj.2013.12.011

Qi Y, Thapa KB, Hoadley AFA (2011) Benefit of lignite as a filter aid for dewatering of digested sewage sludge demonstrated in pilot scale trials. Chem Eng J 166:504-510. https://doi.org/10.1016/j. cej.2010.11.003

Quinlan PJ, Tanvir A, Tam KC (2015) Application of the central composite design to study the flocculation of an anionic azo dye using quaternized cellulose nanofibrils. Carbohydr Polym 133:80-89. https://doi.org/10.1016/j.carbpol.2015.06.095

Rahmanifar B, Moradi-Dehaghi S (2014) Removal of organochlorine pesticides by chitosan loaded with silver oxide nanoparticles from water. Clean Technol Environ Policy 16:1781-1786. https ://doi.org/10.1007/s10098-013-0692-5

Ramli SF, Aziz HA (2015) Use of ferric chloride and chitosan as coagulant to remove turbidity and color from landfill leachate. Appl Mech Mater 773:1163-1167. https://doi.org/10.4028/www.scien tific.net/AMM.773-774.1163

Rani M, Shanker U, Jassal V (2017) Recent strategies for removal and degradation of persistent and toxic organochlorine pesticides using nanoparticles: a review. J Environ Manag 190:208-222. https://doi.org/10.1016/j.jenvman.2016.12.068

Rashid S, Shen C, Yang J, Liu J, Li J (2018) Preparation and properties of chitosan-metal complex: some factors influencing the adsorption capacity for dyes in aqueous solution. J Environ Sci 66:301-309. https://doi.org/10.1016/j.jes.2017.04.033

Ravi Kumar MNV (2000) A review of chitin and chitosan applications. React Funct Polym 46:1-27. https://doi.org/10.1016/S1381 $-5148(00) 00038-9$

Renault F, Badot PM, Crini G (2009a) Chitosan for flocculation processes-an eco-friendly approach. In: Rustichelli F, Caramella, Şenel S, Vårum KM (eds) Advances in chitin science. Proceedings of the 9th International Conference of Chitin and Chitosan, Volume XI, pp 360-366

Renault F, Sancey B, Badot PM, Crini G (2009b) Use of chitosan as a bioflocculant to treat biological wastewater from pulp and paper plant. In: Rustichelli F, Caramella, Şenel S, Vårum KM (eds) Advances in chitin science. Proceedings of the 9th International Conference of Chitin and Chitosan, Volume XI, pp 407-412 
Renault F, Sancey B, Charles J, Morin-Crini N, Badot PM, Winterton P, Crini G (2009c) Chitosan flocculation of cardboard-mill secondary biological wastewater. Chem Eng J 155:775-783. https ://doi.org/10.1016/cej.2009.09.023

Renault F, Sancey B, Badot PM, Crini G (2009d) Chitosan for coagulation/flocculation processes - an eco-friendly approach. Eur Polym J 45:1337-1348. https://doi.org/10.1016/j.eurpo lymj.2008.12.027

Renou S, Givaudan JG, Poulain S, Dirassouyan F, Moulin P (2008) Landfill leachate treatment: review and opportunity. J Hazard Mater 150:468-493. https://doi.org/10.1016/j.jhazm at.2007.09.077

Rinaudo M (2006) Chitin and chitosan: properties and applications. Prog Polym Sci 31:603-632. https://doi.org/10.1016/j.progp olymsci.2006.06.001

Ripperger S, Gösele W, Alt C (2012) Filtration, 1. Fundamentals, vol 14. Wiley, Weinheim, pp 677-709

Roberts GAF (1992) Chitin chemistry, 1st edn. Macmillan Press, London. ISBN13: 9780333524176

Ruelas-Leyva JP, Contreras-Andrade I, Sarmiento-Sanchez JI, LiceaClaverie A, Jimenez-Lam SA, Cristerna-Madrigal YG, PicosCorrales LA (2017) The effectiveness of Moringa oleifera seed flour and chitosan as coagulant-flocculants for water treatment. Clean Soil Air Water 45:1600339. https://doi.org/10.1002/ clen.201600339

Rushdy R, Reza M, McKay G (2014) Combined magnetic field and adsorption process for treatment of biologically treated palm oil mill effluent (POME). Chem Eng J 243:31-42. https://doi. org/10.1016/j.cej.2013.12.084

Saeed MO, Azizli KAM, Isa MH, Ezechi EH (2016) Treatment of POME using Fenton oxidation process: removal efficiency, optimization, and acidity condition. Desalt Water Treat 57:23750-23759. https://doi.org/10.1080/19443 994.2016.1141715

Salehizadeh H, Yan N, Farnood R (2018) Recent advances in polysaccharides bio-based flocculants. Biotechnol Adv 36:92-119. https://doi.org/10.1016/j.biotechadv.2017.10.002

Schindler DW, Hecky RE, McCullough GK (2012) The rapid eutrophication of Lake Winnipeg: greening under global change. J Great Lakes Res 38:6-13

Shankar A, Kongot M, Saini VK, Kumar A (2018) Removal of pentachlorophenol pesticide from aqueous solutions using modified chitosan. Arab J Chem. https://doi.org/10.1016/j.arabj c. 2018.01.016

Skjåk-Braek G, Anthonsen T, Sandford PA (eds) (1989) Chitin and chitosan. Sources, chemistry, biochemistry, physical properties and applications. Elsevier, New York, p 835. ISBN 978-1-85166-395-8

Song Z, Li G, Guan F, Liu W (2018) Application of chitin/chitosan and their derivatives in the papermaking industry. Polymers 10:1-14. https://doi.org/10.3390/polym10040389

Soros A, Amburgey JE, Stauber CE, Sobsey MD, Casanova LM (2019) Turbidity reduction in drinking water by coagulationflocculation with chitosan polymers. J Water Health 17:204218. https://doi.org/10.2166/wh.2019.114

Stechemesser H, Dobiáš B (eds) (2005) Coagulation and flocculation. Surfactant science series, 2nd edn. CRC Press, Boca Raton, volume 126, p 861. ISBN: 9781574444551

Steed JW, Atwood JL (2009) Supramolecular chemistry, 2nd edn. Wiley, West Sussex. ISBN: 9781118681503

Sudha PN (2011) Chitin/chitosan and derivatives for wastewater treatment. In: Kim SK (ed) Chitin, chitosan, oligosaccharides and their derivatives: biological activities and applications. CRC Press, Boca Raton, chapter 39, pp 561-588. ISBN: 9781439816035
Sudha PN, Aisverya S, Gomathi T, Vijayalakshmi K, Saranya M, Sangeetha K, Latha S, Thomas S (2017) Applications of chitin/chitosan and its derivatives as adsorbents, coagulants and flocculants. In: Ahmed S, Ikram S (eds) Chitosan-derivatives, composites and applications. Scrivener Publishing LLC, Wiley, chapter 17, pp 453-487. https://doi.org/10.1002/9781119364 849.ch17

Suopajärvi T, Liimatainen H, Hormi O, Niinimäki J (2013) Coagulation-flocculation treatment of municipal wastewater based on anionized nanocelluloses. Chem Eng J 231:59-67. https://doi. org/10.1016/j.cej.2013.07.010

Tadza MYM, Sobani HHM, Ghani NAF (2015) Characteristics of struvite precipitate from palm oil mill effluent. J Sci Technol Trop 11:1-9

Tadza MYM, Ghani NAF, Sobani HHM (2016) Evaluation of sludge from coagulation of palm oil mill effluent with chitosan based coagulant. Jurnal Teknologi 78:19-22. https://doi.org/10.11113 /jt.v78.8529

Teng D (2016) From chitin to chitosan. In: Yao K, Li J, Yao F, Yin Y (eds) Chitosan-based hydrogels: functions and applications. CRC Press, Boca Raton, chapter 1, pp 1-38. ISBN: 9781138076846

Torres K, Álvarez-Hornos FJ, San-Valero P, Gabaldón C, Marzal P (2018) Granulation and microbial community dynamics in the chitosan-supplemented anaerobic treatment of wastewater polluted with organic solvents. Water Res 130:376-387. https://doi. org/10.1016/j.watres.2017.12.009

Ujang Z, Diah M, Rashid AHA, Halim AS (2011) The development, characterization and application of water soluble chitosan. In: Elnashar M (ed) Biotechnology of biopolymers. InTech, Rijeka, chapter 6, pp 109-130. https://doi.org/10.5772/16771

Ummalyma SB, Gnansounou E, Sukumaran RK, Sindhu R, Pandey A, Sahoo D (2017) Bioflocculation: an alternative strategy for harvesting of microalgae-an overview. Bioresour Technol 242:227-235. https://doi.org/10.1016/j.biortech.2017.02.097

Vajihinejad V, Gumfekar SP, Bazoubandi B, Najafabadi ZR, Soares JBP (2019) Water soluble polymer flocculants: synthesis, characterization, and performance assessment. Macromol Mater Eng 304:1800526. https://doi.org/10.1002/mame.201800526

Van Tran V, Park D, Lee YC (2018) Hydrogel applications for adsorption of contaminants in water and wastewater treatment. Environ Sci Pollut Res 25:24569-24599. https://doi.org/10.1007/s1135 6-018-2605-y

Vårum KM, Smidsrød O (2004) Structure-property relationship in chitosan. In: Dumitriu S (ed) Polysaccharides. Structural diversity and functional versatility. Marcel Dekker, New York, chapter 26, pp 625-641. ISBN: 9780824754808

Verma AK, Dash RR, Bhunia P (2012) A review on chemical/flocculation technologies for removal of colour from textile wastewaters. J Environ Manag 93:154-168. https://doi.org/10.1016/j.jenvm an.2011.09.01

Vidal RRL, Moares JS (2019) Removal of organic pollutants from wastewater using chitosan: a literature review. Int J Environ Sci Technol 16:1741-1754. https://doi.org/10.1007/s1376 2-018-2061-8

Wang J, Zhuang S (2017) Removal of various pollutants from water and wastewater by modified chitosan adsorbents. Crit Rev Environ Sci Technol 47:2331-2386. https://doi.org/10.1080/10643 389.2017 .1421845

Wei H, Gao B, Ren J, Li A, Yang H (2018) Coagulation/flocculation in dewatering of sludge: a review. Water Res 143:608-631. https:// doi.org/10.1016/j.watres.2018.07.029

Wilson LD (2014) An overview of coagulation-flocculation technology. Water Cond Purif Mag 56:28-34

Wilson LD, Tewari BB (2018) Chitosan-based adsorbents: environmental applications for the removal of arsenicals. Mater Res Found 34:133-160. https://doi.org/10.21741/9781945291753-7 
Wilson LD, Pratt DY, Kozinski JA (2013) Preparation and sorption studies of $\beta$-cyclodextrin-chitosan-glutaraldehyde terpolymers. J Colloid Interface Sci 393:271-277. https://doi.org/10.1016/j. jcis.2012.10.046

Wu TY, Mohammad AW, Jahim JM, Anuar N (2010) Pollution control technologies for the treatment of palm oil mill effluent (POME) through end-of-pipe processes. J Environ Manag 91:1467-1490. https://doi.org/10.1016/j.jenvman.2010.02.008

Xu HZ, Pei HY, Xiao HD, Jin Y, Li XQ, Hu WR, Ma CX, Sun JM, Li HM (2016) Behaviors of Microcystis aeruginosa cells during floc storage in drinking water treatment process. Sci Rep 6:34943. https://doi.org/10.1038/srep34943

Yang K, Li Z, Zhang H, Qian J, Chen G (2010) Municipal wastewater phosphorus removal by coagulation. Environ Technol 31:601609. https://doi.org/10.1080/09593330903573223

Yang R, Li H, Huang M, Yang H, Li A (2016) A review on chitosanbased flocculants and their applications in water treatment. Water Res 95:59-89. https://doi.org/10.1016/j.watres.2016.02.068

Yu GH, He PJ, Shao LM, He PP (2008) Stratification structure of sludge flocs with implications to dewaterability. Environ Sci Technol 42:7944-7949. https://doi.org/10.1021/es8016717
Zahrim AY, Tizaoui C, Hilal N (2011) Coagulation with polymers for nanofiltration pre-treatment of highly concentrated dyes: a review. Desalination 266:1-16. https://doi.org/10.1016/j.desal .2010 .08 .012

Zhai LF, Sun M, Song W, Wang G (2012) An integrated approach to optimize the conditioning chemicals for enhanced sludge conditioning in a pilot-scale sludge dewatering process. Bioresour Technol 121:161-168. https://doi.org/10.1016/j.biort ech.2012.06.093

Ziyang L, Youcai Z, Tao Y, Yu S, Huili C, Nanwen Z, Renhua H (2009) Natural attenuation and characterization of contaminants composition in landfill leachate under different disposing ages. Sci Total Environ 407:3385-3391. https://doi.org/10.1016/j.scito tenv.2009.01.028

Publisher's Note Springer Nature remains neutral with regard to jurisdictional claims in published maps and institutional affiliations.

\section{Affiliations}

\section{Eric Lichtfouse ${ }^{1}$ (1) - Nadia Morin-Crini ${ }^{2}$ (1) - Marc Fourmentin ${ }^{3} \cdot$ Hassiba Zemmouri ${ }^{4}$. Inara Oliveira do Carmo Nascimento ${ }^{5} \cdot$ Luciano Matos Queiroz $^{5} \cdot$ Mohd Yuhyi Mohd Tadza $^{6}$. Lorenzo A. Picos-Corrales ${ }^{7} \cdot$ Haiyan Pei $^{8} \cdot$ Lee D. Wilson $^{9} \cdot$ Grégorio Crini $^{2}$ (i)}

Nadia Morin-Crini

nadia.crini@univ-fcomte.fr

Marc Fourmentin

marc.fourmentin@univ-littoral.fr

Hassiba Zemmouri

hassiba_zemmouri@yahoo.fr

Inara Oliveira do Carmo Nascimento

nara.ocn@gmail.com

Luciano Matos Queiroz

lmqueiroz@ufba.br

Mohd Yuhyi Mohd Tadza

dryuhyi@ump.edu.my

Lorenzo A. Picos-Corrales

lorenzo.picos.c@uas.edu.mx

Haiyan Pei

haiyanhup@126.com

Lee D. Wilson

lee.wilson@usask.ca

1 Aix Marseille Univ, CNRS, IRD, INRA, Coll France, CEREGE, Aix-en-Provence, France

2 Laboratoire Chrono-Environnement, UMR 6249,

UFR Sciences et Techniques, Université Bourgogne

Franche-Comté, 16 Route de Gray, 25000 Besançon, France
3 Laboratoire de Physico-Chimie de l'Atmosphère (LPCA, EA 4493), Université du Littoral Côte d'Opale (ULCO), 59140 Dunkerque, France

4 Laboratoire des Sciences et du Génie des Procédés Industriels, Faculté de Génie Mécanique et Génie des Procédés, Université des Sciences et de la Technologie Houari Boumediene, BP 32 El-Alia, 16111 Bab-Ezzouar, Alger, Algeria

5 Department of Environmental Engineering, Polytechnic School, Federal University of Bahia, Aristides Novis Street 2, 4th Floor, Federação, Salvador, Bahia 40210-630, Brazil

6 Faculty of Civil Engineering and Earth Resources, Universiti Malaysia Pahang, Lebuhraya Tun Razak, 26300 Gambang, Kuantan, Malaysia

7 Facultad de Ciencias Químico Biológicas, Universidad Autónoma de Sinaloa, Blvd. de las Américas y Josefa Ortiz de Domínguez, Ciudad Universitaria, 80013 Culiacán, Sinaloa, Mexico

8 School of Environmental Science and Technology, Shandong University, Jinan, China

9 Department of Chemistry, University of Saskatchewan, 110 Science Place, Saskatoon, SK S7N 5C9, Canada 